Environmental Protection Department

Operations and Regulatory Affairs Division

\title{
LLNL NESHAPs 2004 Annual Report
}

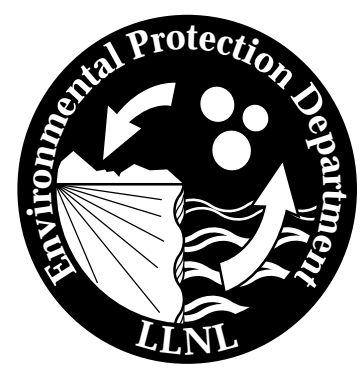

Lawrence Livermore National Laboratory University of California Livermore, California 94551 
This work was performed under the auspices of the U.S. Department of Energy by the University of California, Lawrence Livermore National Laboratory under contract No. W-7405-Eng-48. 


\title{
LLNL NESHAPs 2004 Annual Report
}

\author{
Robert J. Harrach \\ Gretchen M. Gallegos \\ Sylvie-Ring Peterson \\ Kent R. Wilson
}

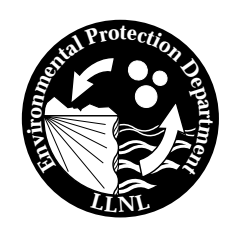

Contributors:

Brent M. Bowen Paris Althouse

Paula Tate 



\section{U.S. Department of Energy \\ Radionuclide Air Emission Annual Report \\ (under Subpart $\mathrm{H}$ of 40 CFR Part 61) \\ Calendar Year 2004}

Site Name: Lawrence Livermore National Laboratory

\section{DOE Site Office Information}

Office: $\quad$ U.S. Department of Energy

Livermore Site Office

Address: $\quad 7000$ East Avenue, L-293

Livermore, CA 94550

Contact: $\quad$ Vijay Mishra

Phone: 925-423-8163

\section{Contractor Site Information}

Operator: University of California

Address: $\quad 7000$ East Avenue

Livermore, CA 94551

Contact: C. Susi Jackson Phone: 925-423-6577 



\section{Table of Contents}

SYNOPSIS ............................................................................................................................1

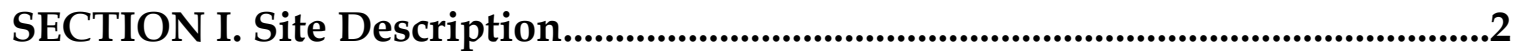

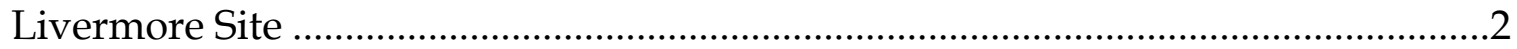

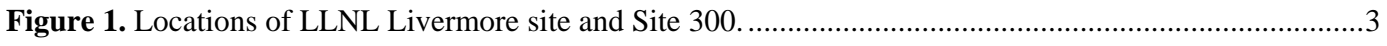

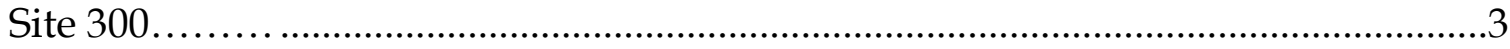

Figure 2. Wind roses, showing wind speed, direction, and frequency of occurrence at the Livermore site and Site 300 during 2004 ....................................................................................................

SECTION II. Air Emission Sources and Data ..............................................................5

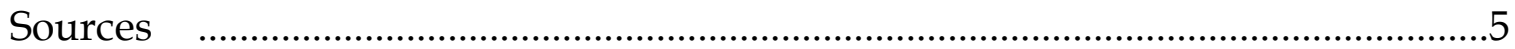

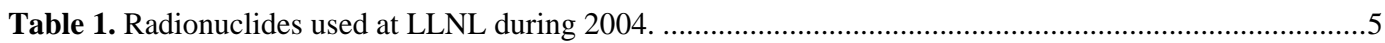

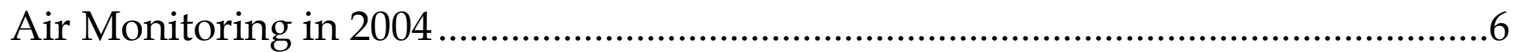

Continuous Stack Air Effluent Monitoring .....................................................6

Table 2. Air effluent sampling systems and locations..............................................................................

Results of stack monitoring for tritium.................................................. 7

Table 3. Combined HT and HTO emissions from the Tritium Facility, 1981-2004....................................8

Stack monitoring for gross alpha and gross beta radiation ............................

Air Surveillance Monitoring for Radioactive Particles and Gases......................9

Compliance Demonstration for Minor Radiological Sources............................10

Table 4. Mean concentrations of radionuclides of concern at the location of the SW-MEI in 2004..............11

Table 5. Facilities with minor radiological emissions (by directorate), for 2004........................................11

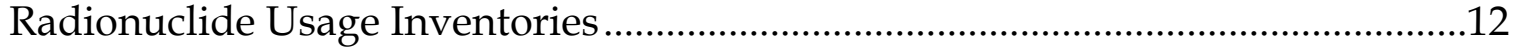

SECTION III. Dose Assessment Methods and Concepts ..........................................12

Description of the Air Dispersion and Dose Model...............................................12

Summary of Model Input Parameters ...........................................................13

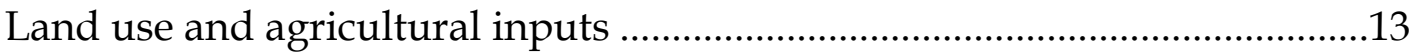

Table 6. Changes to CAP88-PC's agricultural parameter values representing LLNL ..................................13

General model inputs .......................................................................... 14

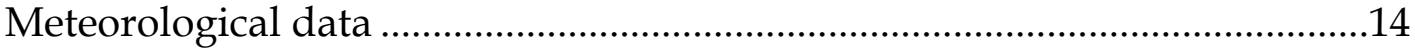

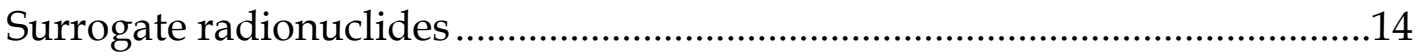

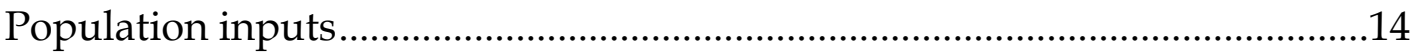

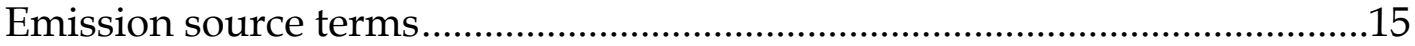

Table 7. List of materials exempted from the "treat as a gas above $100^{\circ} \mathrm{C}$ ” rule, and temperatures

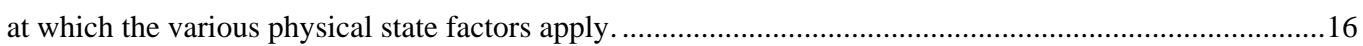

Site-wide maximally exposed individual ................................................16

Figure 3. Location of site-wide maximally exposed individual (SW-MEI) at the Livermore site, 2004 ........17

Maximally exposed public individual ..................................................17

Figure 4. Location of site-wide maximally exposed individual (SW-MEI) at Site 300, 2004 ......................18 
Total Dose to Site-Wide Maximally Exposed Individuals

Table 8. Ranked list of facilities or sources whose emissions accounted collectively for

at least $90 \%$ of the SW-MEI doses for the Livermore site and Site 300 in 2004 .........................................20

Doses from Unplanned Releases ........................................................................20

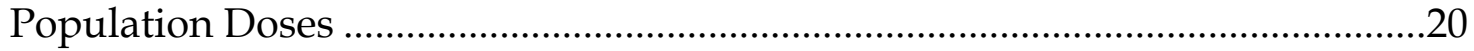

Table 9. Doses (in mrem) calculated for the site-wide maximally exposed individual (SW-MEI)

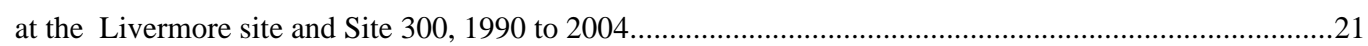

Table 10. Disaggregations of collective dose for the Livermore site, 2004 ...............................................22

Table 11. Disaggregations of collective dose for Site 300, 2004 ...............................................................22

Compliance with 40 CFR 61 Subpart H (61.93) .....................................................23

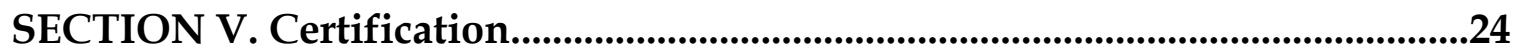

SECTION VI. Supplemental Information on NESHAPs Compliance and

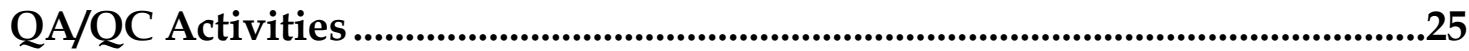

Use of Surveillance Air Monitoring in Demonstrating NESHAPs Compliance for LLNL's Numerous Minor Sources ...........................................25

Periodic Confirmatory Measurements................................................................25

Implementation of the ANSI/HPS N13.1-1999 Stack Sampling Standard for a 2004 New Activity.....................................................................................26

NESHAPs Quality Assurance (QA) Program......................................................26

Evaluation of New Radiological Projects ............................................................27

Quality Control (QC) for 2004 Air Dispersion and Dose Assessment Model Runs and Radiological Usage Inventories .............................................28

Changes in Operations and Facilities for Radioactive and Hazardous

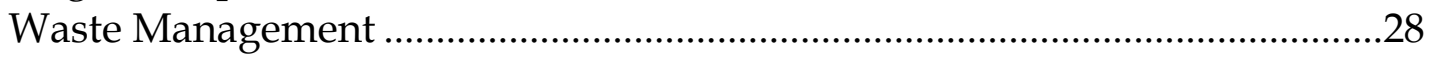

\section{SECTION VII. Supplementary Information on Radiological Dose Assessment}

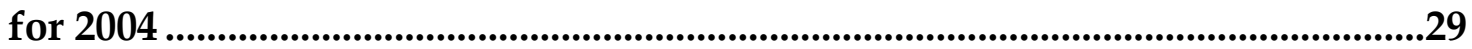

Livermore Site Principal Diffuse Sources ........................................................29

Building 331 Outside Yard Waste Accumulation Area....................................29

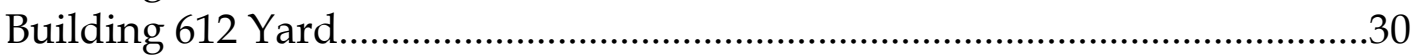

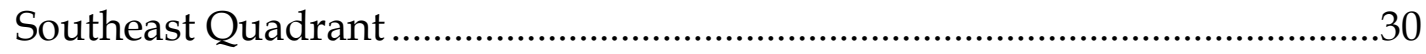

Site 300 Principal Diffuse Sources .........................................................................31

Tritium Evaporation and Migration at Site 300 …….........................................31

Resuspension of Depleted Uranium in Soil at Site 300 ....................................31

Modeling Dose from Tritium .................................................................................32

Comparison of 2004 Modeling Results with Tritium Surveillance

Air Monitoring Data. 33 
LLNL NESHAPs Report 2004

Figure 5. Radiological air monitoring at the Livermore site, showing locations for air surveillance monitoring of tritiated water vapor (triangles) and radioactive particles (circles), and stack air effluent monitoring (indicated by building number and icon)

Table 12. Comparison of measured and modeled annual mean concentrations of tritiated water vapor (HTO) in air at selected Livermore site locations, 2004.

SECTION VIII. Supplemental Information on Other Compliance........................36

Status of Compliance with Other Regulations ........................................................36

Status of Compliance with 40 CFR 61 Subpart Q - National Emission

Standards for Radon Emissions from Department of Energy Facilities .....36

Status of Compliance with 40 CFR 61 Subpart T - National Emission

Standards for Radon Emissions from the Disposal of Uranium

Mill Tailings

Attachment. LLNL NESHAPs 2004 Annual Report Spreadsheet..........................37

Guidance for Interpreting the Data Spreadsheet .....................................................37

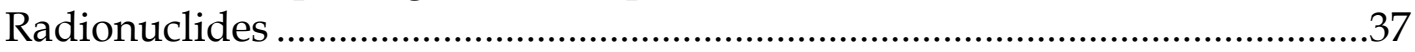

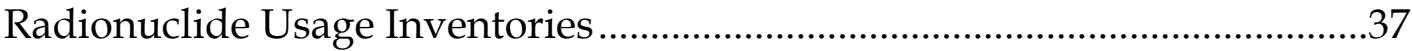

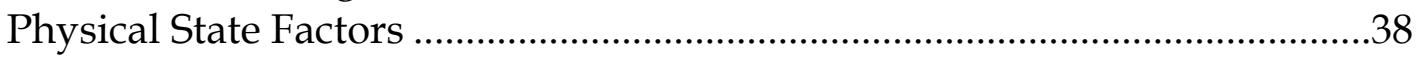

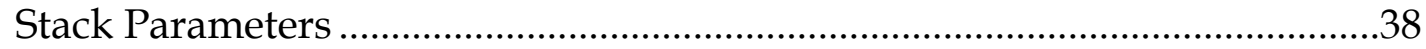

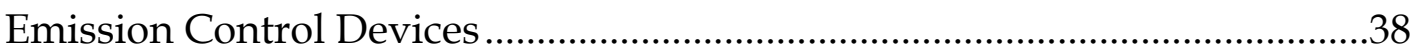

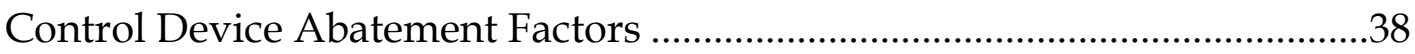

Estimated Annual Emissions ……………………….......................................38

10 mrem/y Site-Wide Dose Requirement .........................................................39

$0.1 \mathrm{mrem} / \mathrm{y}$ Monitoring Requirement ...............................................................39

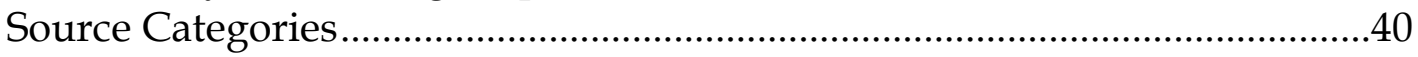





\section{Lawrence Livermore National Laboratory NESHAPs 2004 Annual Report}

This annual report is prepared pursuant to the National Emission Standards for Hazardous Air Pollutants (NESHAPs; Title 40 Code of Federal Regulations [CFR] Part 61, Subpart H). Subpart H governs radionuclide emissions to air from Department of Energy (DOE) facilities.

\section{SYNOPSIS}

NESHAPs limits the emission of radionuclides to the ambient air from DOE facilities to levels resulting in an annual effective dose equivalent (EDE) of 10 mrem $(100 \mu \mathrm{Sv})$ to any member of the public. The EDEs for the Lawrence Livermore National Laboratory (LLNL) site-wide maximally exposed members of the public from operations in 2004 are summarized here.

- $\quad$ Livermore site: 0.0079 mrem $(0.079 \mu \mathrm{Sv})(27 \%$ from point-source emissions, $73 \%$ from diffuse-source emissions). The point-source emissions include gaseous tritium modeled as tritiated water vapor as directed by EPA Region IX; the resulting dose is used for compliance purposes.

- $\quad$ Site 300: 0.026 mrem (0.26 $\mu \mathrm{Sv})(97 \%$ from point-source emissions, 3\% from diffuse-source emissions).

The EDEs were calculated using the EPA-approved CAP88-PC air dispersion/doseassessment model, except for doses for two diffuse sources that were estimated using measured radionuclide concentrations and dose coefficients. Specific inputs to CAP88-PC for the modeled sources included site-specific meteorological data and source emissions data, the latter variously based on continuous stack effluent monitoring data, stack flow or other release-rate information, radionuclide usage inventories, ambient air monitoring data, and facility knowledge. 


\section{SECTION I. Site Description}

LLNL, a U.S. DOE facility operated by the University of California, was established in 1952 to conduct nuclear weapons research and development. The Laboratory serves as a national resource in science, engineering, and technology. LLNL's primary mission focuses on nuclear weapons and national security, including stockpile stewardship. Its mission is dynamic and has been broadened over the years to include areas such as strategic defense, nonproliferation, homeland security, energy, the environment, bioscience and biotechnology, and science and mathematics education. LLNL comprises two sites - the main laboratory site located in Livermore, California (Livermore site), and the Experimental Test Facility (Site 300) located near Tracy, California. Figure 1 shows the locations of the sites.

\section{Livermore Site}

LLNL's Livermore site occupies an area of $3.3 \mathrm{~km}^{2}$ located about $60 \mathrm{~km}$ east of San Francisco, California, adjacent to the City of Livermore in the eastern part of Alameda County. In round numbers, 7 million people live within $80 \mathrm{~km}$ of the Livermore site; about 80,000 of them live in the City of Livermore.

The Livermore site is located in the southeastern portion of the Livermore Valley, a topographical and structural depression oriented east-west within the Diablo Range of the California Coast Range Province. The Livermore Valley forms an irregularly shaped lowland area approximately $26 \mathrm{~km}$ long and an average of $11 \mathrm{~km}$ wide. The floor of the valley slopes from an elevation of approximately $200 \mathrm{~m}$ above sea level at the eastern end to approximately $90 \mathrm{~m}$ above sea level at the southwest corner.

The climate of the Livermore Valley is characterized by mild, rainy winters and warm, dry summers. The mean daily maximum, minimum, and average temperatures for the Livermore site in 2004 were $22.0^{\circ} \mathrm{C}, 8.1^{\circ} \mathrm{C}$, and $15.0^{\circ} \mathrm{C}$, respectively, typical for the site. Temperatures typically range from $-5^{\circ} \mathrm{C}$ during some pre-dawn hours in the winter, to $40^{\circ} \mathrm{C}$ on a few summer afternoons. The 2004 annual wind data for the Livermore site are displayed as a wind rose in Figure 2. In the wind rose, the length of each spoke is proportional to the frequency at which the wind blows from the indicated direction; different line widths of each spoke represent wind speed classes. These data show that $52 \%$ of the time the winds blow from the south-southwest through west directions. However, during the winter, the wind often blows from the northeast. The average wind speed in 2004 at the Livermore site was $2.5 \mathrm{~m} / \mathrm{s}(5.6 \mathrm{mph})$. Most precipitation occurs as rain between October and April with very little rainfall during the summer months. In 2004, the Livermore site received $27.8 \mathrm{~cm}$ of precipitation. 


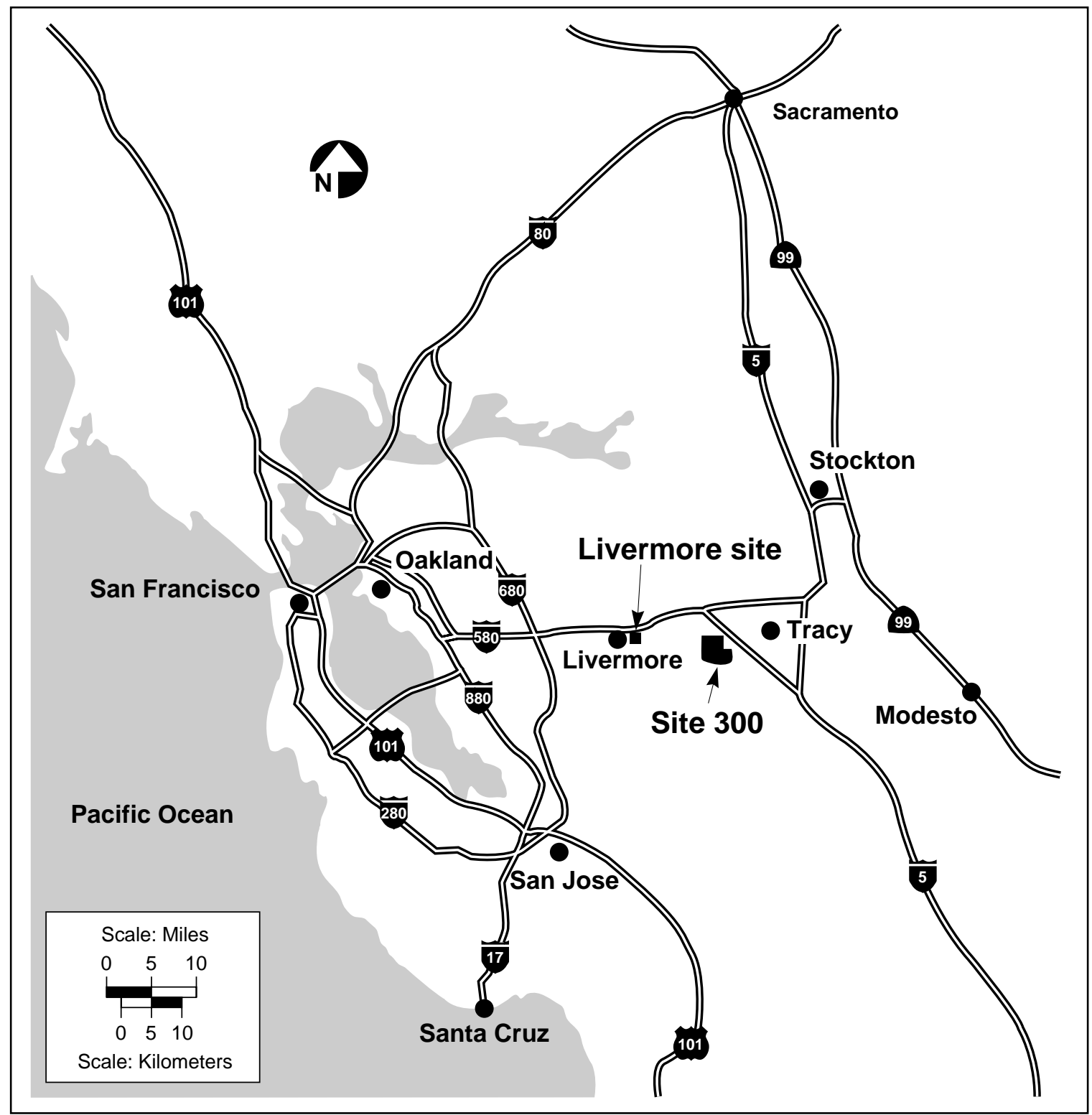

Figure 1. Locations of LLNL's Livermore site and Site 300.

\section{Site $\mathbf{3 0 0}$}

Site 300, LLNL's Experimental Test Facility, is located $24 \mathrm{~km}$ east of the Livermore site in the Altamont Hills of the Diablo Range and occupies an area of $30.3 \mathrm{~km}^{2}$. A State of California vehicular-recreation area is located nearby, and wind-turbine generators line the surrounding hills. The remainder of the surrounding area is in agricultural use, primarily pasture land for cattle and sheep. The nearest residential area is the city of Tracy (population approximately 76,500), located $10 \mathrm{~km}$ to the northeast. 
The topography of Site 300 is much more irregular than that of the Livermore site; it consists of a series of steep hills and ridges, which are oriented along a generally northwest/southeast trend, separated by intervening ravines. The elevation ranges from approximately $540 \mathrm{~m}$ in the northwestern portion of the site to $150 \mathrm{~m}$ at the southeast corner. The climate at Site 300 is similar to that of the Livermore site, with mild winters and dry summers. The complex topography of the site significantly influences local wind and temperature patterns. The stronger winds occurring at the higher elevations of Site 300 results in warmer nights and slightly cooler days than at the Livermore site.

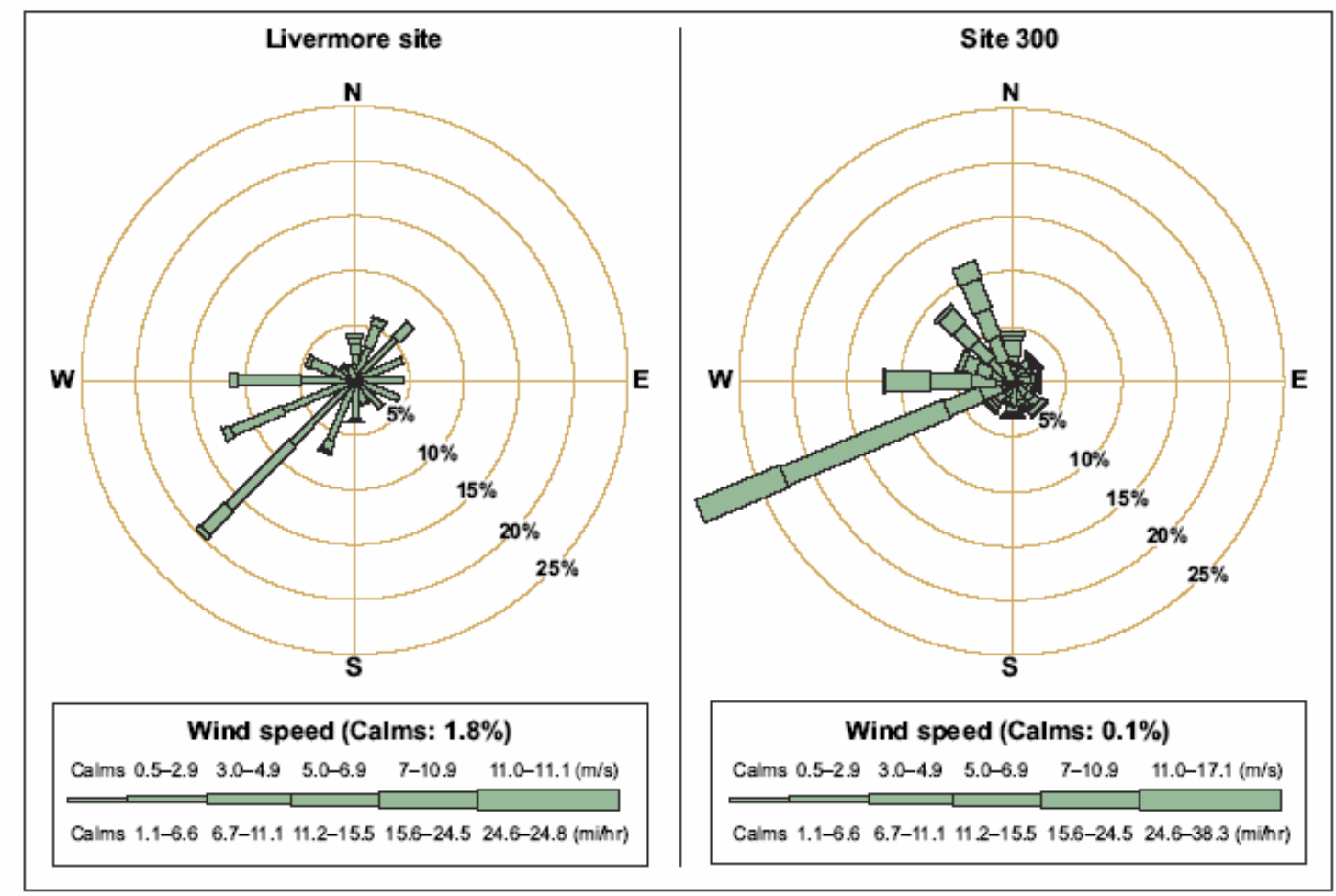

Note: The length of each spoke is proportional to the frequency at which the wind blows from the indicated direction. Different line widths of each spoke represent wind speed classes. The average wind speed in 2004 at the Livermore site was $2.5 \mathrm{~m} / \mathrm{s}$ (5.6 mph); at Site 300 it was $6.1 \mathrm{~m} / \mathrm{s}(13.7 \mathrm{mph})$.

Figure 2. Wind roses, showing wind speed, direction, and frequency of occurrence at the Livermore site and Site 300 during 2004.

The 2004 annual wind data for Site 300 are displayed as a wind rose on the right side of Figure 2. Prevailing winds are from the west-southwest. As is the case at the Livermore site, precipitation is highly seasonal, with most precipitation occurring between October and April. Site 300 received $20.2 \mathrm{~cm}$ of precipitation during 2004 and had mean daily maximum, minimum, and average temperatures of $20.8^{\circ} \mathrm{C}$, $12.1^{\circ} \mathrm{C}$, and $16.5^{\circ} \mathrm{C}$, respectively. The average wind speed at the site was $6.1 \mathrm{~m} / \mathrm{s}$ (13.7 mph). 


\section{SECTION II. Air Emission Sources and Data}

\section{Sources}

Eighty different radioisotopes were reported for use at LLNL in 2004 for research purposes, including biomedical tracers, tritium, mixed fission products, transuranic isotopes, and others - see Table 1. Radioisotope handling procedures and work enclosures are determined for each project or activity, depending on the isotopes, the quantities being used, and the types of operations being performed. Work enclosures include gloveboxes, exhaust hoods, and laboratory bench tops. Exhaust paths to the atmosphere include HEPA (High Efficiency Particulate Air) filtered ventilation systems, roof vents and stacks lacking abatement devices, direct open-air dispersal of depleted uranium during explosives testing at Site 300, and releases to ambient air from a variety of diffuse area sources.

Table 1. Radionuclides used at LLNL during 2004.

\begin{tabular}{llllll}
\hline Hydrogen-3 & Manganese-54 & Technetium-99 & Rhenium-187 & Thorium-230 & Uranium-238 \\
Nitrogen-13 & Iron-55 & Cadmium-109 & Mercury-203 & Palladium-231 & Plutonium-239 \\
Carbon-14 & Cobalt-57 & Silver-110m & Thallium-204 & Protactinium-231 & Plutonium-240 \\
Oxygen-15 & Nickel-59 & Iodine-125 & Bismuth-207 & Thorium-232 & Americium-241 \\
Sodium-22 & Cobalt-60 & Iodine-131 & Polonium-208 & Uranium-232 & Plutonium-241 \\
Phosphorus-32 & Nickel-63 & Barium-133 & Polonium-209 & Uranium-233 & Americium-242m \\
Phosphorus-33 & Zinc-65 & Cesium-134 & Polonium-210 & Uranium-234 & Plutonium-242 \\
Sulfur-35 & Selenium-75 & Cesium-137 & Lead-210 & Uranium-235 & Americium-243 \\
Chlorine-36 & Krypton-85 & Cerium-144 & Radium-226 & Neptunium-236 & Curium-243 \\
Potassium-40 & Strontium-85 & Promethium-147 & Actinium-227 & Plutonium-236 & Curium-244 \\
Calcium-41 & Yttrium-88 & Europium-152 & Radium-228 & Uranium-236 & Plutonium-244 \\
Argon-41 & Strontium-89 & Europium-154 & Thorium-228 & Neptunium-237 & Californium-249 \\
Chromium-51 & Strontium-90 & Europium-155 & Thorium-229 & Uranium-237 & Californium-250 \\
& & & & Plutonium-238 & Californium-252 \\
\hline
\end{tabular}

Sources of radioactive material emissions to air at LLNL are divided into two categories for purposes of evaluating NESHAPs compliance: point sources and diffuse area sources. The former includes stacks, roof vents, and explosive experiments conducted on Site 300's firing tables; the latter are for the most part dedicated waste accumulation areas and other areas of known contamination, generally external to buildings. 


\section{Air Monitoring in 2004}

Continuous stack-effluent sampling systems at selected LLNL facilities and ambient air monitors in place at numerous locations on and off LLNL sites are described in this section.

\section{Continuous Stack Air Effluent Monitoring}

Actual measurements of radioactivity in air and effluent flow are the basis for reported emissions from continuously monitored sources. In 2004, there were six buildings (Buildings 235, 251, 331, 332, 491, and 695/696; the last two share a common stack) at the Livermore site and one building (the Contained Firing Facility, Building $801 \mathrm{~A}$ ) at Site 300 that had radionuclide air effluent monitoring systems. These buildings are listed in Table 2, along with the number of samplers, the types of samplers, and the analytes of interest.

Air samples for particulate emissions are extracted downstream of HEPA filters and prior to the discharge point to the atmosphere. Particles are collected on membrane filters. The sample filters are removed and analyzed for gross alpha and beta activity on a weekly or bi-weekly frequency depending on the facility. In most cases, passive filter aerosol collection systems are used. However, in some facilities, alpha continuous air monitors (CAMs) are used for sampling. In addition to collecting a sample of particles, the CAM units provide an alarm capability for the facility in the event of an unplanned release of alpha activity.

Detection of gross alpha and beta activity resulting from particles collected on the air filters is accomplished using gas flow proportional counters. Analysis is delayed for at least four days from the end of sample collection to allow for the decay of naturally occurring radon daughters. For verification of the operation of the counting system, calibration sources, as well as background samples, are intermixed with the sample filters for analysis. The Radiological Measurements Laboratory (RML) in LLNL's Hazards Control Department (HCD) performs analyses.

Each stack of the Tritium Facility (Building 331) is monitored for tritium release by both an alarmed continuous monitoring system and by molecular sieve continuous samplers. The alarmed monitors provide real time tritium concentration release levels (HT, HTO, or other gaseous forms). The sieve samplers discriminate between tritiated water (HTO) vapor and molecular tritium (HT); they provide the values used for environmental reporting and are exchanged weekly. Each sieve sampler (not alarmed) is in parallel with an alarmed monitor and consists of two molecular sieves. The first sieve collects tritiated water vapor; the second sieve contains a palladium-coated catalyst that converts molecular tritium to tritiated water, which is then collected. The molecular sieve samples are submitted to the Hazards Control Analytical Laboratory where they are put into a recovery system for the bake out of tritiated water vapor and subsequent condensation and collection of the water. The 
retrieved tritiated water is analyzed by RML using liquid scintillation counting techniques.

Environmental Protection Department (EPD) environmental analysts review data from air particulate sampling filters and molecular sieves.

Table 2. Air effluent sampling systems and locations.

\begin{tabular}{|c|c|c|c|c|}
\hline Building & Facility & Analytes & Sample type & $\begin{array}{c}\text { Number of } \\
\text { samplers }\end{array}$ \\
\hline 235 & Chemistry and Materials Science & Gross $\alpha, \beta$ on particles & Filter & 1 \\
\hline 251 & Heavy Elements & & & \\
\hline \multirow{4}{*}{331} & Unhardened ${ }^{\mathrm{a}}$ area & Gross $\alpha, \beta$ on particles & Filters & 23 \\
\hline & Hardened $^{\mathrm{a}}$ area & Gross $\alpha, \beta$ on particles & Filters & 4 \\
\hline & Tritium & Tritium & Ionization Chamber ${ }^{b}$ & 4 \\
\hline & & $\begin{array}{l}\text { Gaseous tritium/ } \\
\text { tritiated water vapor }\end{array}$ & Molecular sieves & 4 \\
\hline \multirow[t]{2}{*}{332} & Plutonium & Gross $\alpha, \beta$ on particles & $\mathrm{CAM}^{\mathrm{b}}$ & 12 \\
\hline & & Gross $\alpha, \beta$ on particles & Filters & 15 \\
\hline 491 & Isotope Separation ${ }^{\mathrm{C}}$ & Gross $\alpha, \beta$ on particles & Filter & 1 \\
\hline 695 & $\begin{array}{l}\text { Decontamination and } \\
\text { Waste Treatment Facility }\end{array}$ & Gross $\alpha, \beta$ on particles & Filter & 1 \\
\hline 695 Yard & TRU Mover & Gross $\alpha, \beta$ on particles & Filter & 1 \\
\hline $801 \mathrm{~A}$ & Contained Firing Facility & Gross $\alpha, \beta$ on particles & Filter & 1 \\
\hline
\end{tabular}

Note: "CAM" denotes Eberline continuous air monitors.

a Hardening refers to seismic reinforcement.

b Alarmed systems.

c Isotope separation operations were discontinued; area now used for storage of contaminated parts.

Results of Stack Monitoring for Tritium: Operations in the Tritium Facility (Building 331) in 2004 released a total of $16.5 \mathrm{Ci}\left(6.1 \times 10^{11} \mathrm{~Bq}\right)$ of tritium. Of this, approximately $12.1 \mathrm{Ci}\left(4.5 \times 10^{11} \mathrm{~Bq}\right)$ were released as tritiated water $(\mathrm{HTO})$. The remaining tritium released, $4.4 \mathrm{Ci}\left(1.6 \times 10^{11} \mathrm{~Bq}\right)$, was elemental tritium gas $(\mathrm{HT})$. The highest single weekly stack emission from the facility was $2.6 \mathrm{Ci}\left(9.6 \times 10^{10} \mathrm{~Bq}\right)$.

This 2004 level of tritium emissions was lower than those typically seen, indicative of a reduced level of operations in the Tritium Facility. Table 3 displays the combined HTO and HT emissions from the Tritium Facility since 1981. 
Monitored tritium releases from the stack of the new Decontamination and Waste treatment Facility (DWTF) in 2004 are discussed under the subheading "Periodic Confirmatory Measurements" in Section VI.

Table 3. Combined HT and HTO emissions from the Tritium Facility, 1981-2004.

\begin{tabular}{cc|cc}
\hline Year & $\begin{array}{c}\text { Tritium emissions }^{\mathbf{a}, \mathbf{b}} \\
(\mathbf{C i})\end{array}$ & Year & $\begin{array}{c}\text { Tritium emissions } \mathbf{a}, \mathbf{b} \\
(\mathbf{C i})\end{array}$ \\
\hline 2004 & 17 & 1992 & 177 \\
2003 & 110 & 1991 & $964(148)$ \\
2002 & 36 & 1990 & 1281 \\
2001 & 20 & 1989 & $2620(329)$ \\
2000 & 40 & 1988 & 3978 \\
1999 & 280 & 1987 & 2634 \\
1998 & 109 & 1986 & 1128 \\
1997 & 299 & 1985 & $989(1000)$ \\
1996 & 215 & 1984 & $2200(5000)$ \\
1995 & 92 & 1983 & 3024 \\
1994 & 137 & 1982 & 1914 \\
1993 & 237 & 1981 & 2552 \\
\hline
\end{tabular}

a Doses calculated from these emissions include HT releases modeled as HTO, as directed by EPA Region IX. EPA Region IX acknowledges that such modeling results in an over-estimation of the tritium dose.

b Chronic releases from normal operations are distinguished from acute accidental releases by showing the latter in parentheses. Accidental releases are predominately HT gas.

Stack Monitoring for Gross Alpha and Gross Beta Radiation: For most discharge points at the other facilities where continuous stack sampling is performed, the results are below the minimum detectable concentration (MDC) of the analysis; sometimes as few as 1 to 4 samples (out of 26 to 52 per year) have concentrations greater than the MDC. Generally, these few samples having results above the MDC are only marginally above it. Use of zero values for this type of data can be justified based on knowledge of the facility; the use of tested, multiple stage, HEPA filters in all significant release pathways; and alpha-spectrometry-based isotopic analyses of selected air sampling filters. These isotopic analyses demonstrate that detected activity on air sampling filters comes from naturally occurring radionuclides, such as radon daughters, e.g., polonium, on the air sampling filters. In addition, because of exhaust configurations at some facilities, the monitoring systems sometimes sample air from the ambient atmosphere along with the HEPA filtered air from facility operations, giving rise to background atmospheric radioactivity being collected. Because of these considerations, the emissions from such facility operations are reported as zero. As a result, there are no dose consequences, and doses reported for these operations are zero. Furthermore, even if the MDC values were used in calculations of the emission estimates for these 
facilities, which would be an extremely conservative approach, the total dose attributable to LLNL activities would not be significantly affected.

In 2004, a significant number of samples collected throughout the year from two release emission points at Building 251 (the unhardened area) yielded gross alpha results slightly greater than the MDC. Gross alpha is used as the primary indicator of potential emissions for operations that involve the use of uranium and transuranic materials, such as those at Building 251. The gross alpha and gross beta activity emissions for Building 251 were $5.0 \times 10^{-9} \mathrm{Ci} / \mathrm{y}\left(1.9 \times 10^{2} \mathrm{~Bq} / \mathrm{y}\right)$ and $4.3 \times 10^{-8}$ $\mathrm{Ci} / \mathrm{y}\left(1.6 \times 10^{3} \mathrm{~Bq} / \mathrm{y}\right)$. Because of the number of samples with values above the MDC, we have taken a conservative approach and are reporting gross alpha and gross beta measurements as actual emissions.

The resulting radiological dose determined with CAP88-PC modeling was $6.8 \times 10^{-7}$ mrem/y $\left(6.8 \times 10^{-6} \mu \mathrm{Sv} / \mathrm{y}\right)$; doses are discussed in Sections III and IV and in the Attachment.

Among the facilities monitored for particulate gross alpha and beta in 2004, only Building 251 showed emissions .

\section{Air Surveillance Monitoring for Radioactive Particles and Gases}

Surveillance air monitoring for tritium and radioactive particles has been in place since the early 1970s. LLNL currently maintains seven continuously operating, high volume, air particulate samplers on the Livermore site, nine in the Livermore Valley, eight at Site 300, and one in Tracy. LLNL also maintains eleven continuously operating tritiated water vapor samplers on the Livermore site, six samplers in the Livermore Valley and one at Site 300. The samplers are positioned to provide reasonable probability that any significant airborne concentration of particulate or tritiated water vapor effluents resulting from LLNL operations will be detected. Several surveillance air monitors are placed near diffuse emission sources, such as those near Building 331 and in the Building 612 Yard, as well as in and around the Southeast Quadrant of the Livermore site. As such, their results can be used to estimate and/or confirm emissions from associated diffuse sources. Both an air particulate monitor and an ambient air tritium sampler are positioned at the location of the hypothetical maximally-exposed member of the public (defined in Section III) for the Livermore site. Data from air surveillance monitors provide a valuable test of predictions based on air dispersion modeling, and can help characterize unplanned releases of radioactive material.

Data from the surveillance air-monitoring network are presented annually in the LLNL Site Annual Environmental Report (SAER), which is available to the public in hardcopy form, on CD, and on the Internet at the address http:/ / www.llnl.gov/saer. 


\section{Compliance Demonstration for Minor Radiological Sources}

From 1991 to 2002, LLNL demonstrated compliance for minor sources (which are primarily non-monitored stack sources) through a labor-intensive inventory and modeling process. The dose consequences to the public for these sources were 8 to 20 orders of magnitude below the regulatory standard of $10 \mathrm{mrem} / \mathrm{y}$ and never affected LLNL's reported dose. To better allocate resources, LLNL made a request, pursuant to the NESHAPs regulations, to use existing ambient air monitoring to demonstrate compliance for minor emissions sources. This request was made in March 2003 and granted in April 2003; see Attachment 3 in the 2002 NESHAPs annual report (Harrach et al., LLNL NESHAPs 2002 Annual Report, UCRL-ID-11386703, June 2003). The present report marks the second year NESHAPs compliance for LLNL's minor sources was demonstrated using the new method.

Basically, the method entails comparing measured ambient air concentrations at the location of the SW-MEI to concentration limits set by the U.S. EPA in its Table 2 Appendix E to 40 CFR 61. The radionuclides for which the comparison is made are tritium and plutonium-239+240 for the Livermore SW-MEI and uranium-238 for the Site 300 SW-MEI. At the Livermore site, the average of the monitoring results for locations VIS and CRED (shown in Figure 5 in Section VII) represent the SW-MEI for the purposes of this minor source comparison. At Site 300, wind-driven resuspension of soil contaminated with depleted uranium is of greatest interest in the minor source category. Because this is a diffuse source covering a wide area, the average of the results for all monitoring locations at the site is used to represent the SW-MEI.

The measured concentrations at the SW-MEI are presented in Table 4, along with EPA's standards from Table 2 Appendix E to 40 CFR 61. As demonstrated by the calculation of the fraction of the standard, LLNL measured concentrations for tritium and plutonium-239+240, and uranium-238 in air are a fraction 0.005 or less of the standard for these radionuclides.

The LLNL radiological facilities included in the "minor sources" classification in 2004 are listed in Table 5. 
Table 4. Mean concentrations of radionuclides of concern at the location of the SW-MEI in 2004, compared to EPA's concentration standard.

\begin{tabular}{|c|c|c|c|c|c|}
\hline Location & Nuclide & $\begin{array}{c}\text { EPA's Table } 2 \\
\text { concentration } \\
\text { standard }\end{array}$ & $\begin{array}{c}\text { Mean } \\
\text { measured } \\
\text { concentration }\end{array}$ & $\begin{array}{c}\text { Measured } \\
\text { concentration } \\
\text { as a fraction of } \\
\text { the standard }\end{array}$ & $\begin{array}{c}\text { Detection } \\
\text { limit }\end{array}$ \\
\hline $\begin{array}{l}\text { Livermore site } \\
\text { SW-MEI }\end{array}$ & Tritium & $\begin{array}{c}1.5 \times 10^{-9} \\
\mathrm{Ci} / \mathrm{m}^{3}\end{array}$ & $\begin{array}{c}1.3 \times 10^{-12} \\
\mathrm{Ci} / \mathrm{m}^{3^{*}}\end{array}$ & $8.7 \times 10^{-4}$ & $\begin{array}{c}1 \times 10^{-12} \\
\mathrm{Ci} / \mathrm{m}^{3}\end{array}$ \\
\hline $\begin{array}{l}\text { Livermore site } \\
\text { SW-MEI }\end{array}$ & Plutonium-239 & $\begin{array}{c}2.0 \times 10^{-15} \\
\mathrm{Ci} / \mathrm{m}^{3}\end{array}$ & $\begin{array}{c}1.3 \times 10^{-19} \\
\mathrm{Ci} / \mathrm{m}^{3 * *}\end{array}$ & $6.5 \times 10^{-5}$ & $\begin{array}{c}5 \times 10^{-19} \\
\mathrm{Ci} / \mathrm{m}^{3}\end{array}$ \\
\hline Site 300 SW-MEI & Uranium-238 & $\begin{array}{c}8.3 \times 10^{-15} \\
\mathrm{Ci} / \mathrm{m}^{3}\end{array}$ & $\begin{array}{l}3.9 \times 10^{-17} \\
\mathrm{Ci} / \mathrm{m}^{3^{* * *}}\end{array}$ & $4.7 \times 10^{-3}$ & $\begin{array}{c}3 \times 10^{-20} \\
\mathrm{Ci} / \mathrm{m}^{3}\end{array}$ \\
\hline
\end{tabular}

* The measured tritium value includes contributions from all tritium sources, i.e., the Tritium Facility, Building 612 Yard, the DWTF stack, the Building 331 Outside WAA, etc.; there is no way to distinguish tritium by its source of emission.

** Note that the mean measured concentration for plutonium is less than the detection limit; only 3 of the 24 values comprising the mean were measured detections.

*** The mean ratio for uranium-235/uranium-238 for 2003 is 0.0068 , which is less than 0.00726 , the ratio of these isotopes for naturally occurring uranium. This indicates that approximately $90 \%$ of the measured quantities of uranium-238 were caused by resuspension of soil containing naturally occurring uranium.

Table 5. Buildings with minor radiological emissions (by directorate), for 2004. ${ }^{\text {a }}$

\begin{tabular}{ccccccccc}
\hline C\&MS & P\&AT & SEP & E\&E & Eng. & Biosci. & DNT & NIF & Institut. \\
\hline B 132 & B 194 & B 253 & B 281 & B 131 & B 361 & B 801 & B 298 & B 212 \\
B 151 & B 282 & B 254 & B 292 & B 231 & B 362 & B 804 & & (vacant) \\
B 235 & B 341 & B 255 & B 378 & B 321 & B 363 & & & \\
B 241 & & & & B 321A & B 364 & & \\
B 810A & & & B 321B & B 365 & & \\
B 810B & & & B 321C & B 366 & & \\
& & & B 322 & & & \\
& & & B 327 & & & & \\
\hline
\end{tabular}

a Directorate abbreviations refer to Chemistry and Materials Science, Physics and Advanced Technologies, Safety and Environmental Protection, Energy and Environment, Engineering, Biosciences, Defense and Nuclear Technologies, National Ignition Facility, and Institutional (Deputy Director for Operations). 


\section{Radionuclide Usage Inventories}

Reliance upon radionuclide usage inventory forms was much reduced in 2003 and 2004 due to implementation of LLNL's new emissions accounting method for minor sources, described in the previous section and in Attachment 3 of the 2002 NESHAPs annual report. Inventories were utilized in 2004 to calculate public dose impacts only for the open-air explosives experiments at Site 300 (see the Attachment) and for prestart evaluations for various other radiological activities/experiments that commenced operations in 2004.

Radionuclide usage inventory forms are archived in the NESHAPs data library maintained by the Terrestrial and Atmospheric Monitoring and Modeling (TAMM) Group in the Operations and Regulatory Affairs Division of the Environmental Protection Department

\section{SECTION III. Dose Assessment Methods \& Concepts}

\section{Description of the Air Dispersion and Dose Model}

Most estimates of individual and collective radiological doses to the public from LLNL operations were obtained using the EPA-developed computer code CAP88PC. The four principal pathways - internal exposures from inhalation of air, ingestion of foodstuff and (for tritium only) drinking water, external exposures through irradiation from contaminated ground, and immersion in contaminated air - are evaluated by CAP88-PC. The doses are expressed as whole-body effective dose equivalents (EDEs), in units of mrem/y $(1 \mathrm{mrem}=10 \mu \mathrm{Sv})$. Separate doses for Livermore site and Site 300 emissions are reported. For purposes of comparison, tritium doses from inhalation and ingestion were also calculated with an improved tritium model, NEWTRIT (see "Modeling Dose from Tritium" in Section VII); NEWTRIT is not yet approved by EPA for use in regulatory compliance evaluations.

Three potential doses are emphasized: (1) The dose to the site-wide maximally exposed individual (SW-MEI), which combines the contributions of all evaluated emission points to dose at a publicly-accessible facility for comparison to the 10 mrem/y (100 $\mu \mathrm{Sv} / \mathrm{y})$ standard; (2) the maximum dose to any member of the public, in any direction attributed to each unabated emission point on the site to determine the need for continuous monitoring; and (3) the collective dose to populations residing within $80 \mathrm{~km}$ of the two LLNL sites, summing the products of individual doses received and number of people receiving them. 


\section{Summary of Model Input Parameters}

Land Use and Agricultural Inputs: In the past, LLNL has used the California default values for agricultural parameters in CAP88-PC. In 2004, EPA suggested that users reconsider the default values and replace them with more appropriate ones. Based on data from the California Department of Food and Agriculture (CDFA 2002; California Department of Food and Agriculture Resource Directory 2002; http://www.dcfa.ca.gov/card/card_new02.htm), LLNL calculated new mean values for California. The default and updated mean values are shown in Table 6.

Table 6. Changes to CAP88PC's agricultural parameter values representing LLNL.

\begin{tabular}{lcc}
\hline Parameter & Default Value & Updated value \\
\hline Beef cattle density (\# cows $\left./ \mathrm{km}^{2}\right)$ & 0.0881 & 1.9 \\
Milk cattle density (\# cows $\left./ \mathrm{km}^{2}\right)$ & 0.0285 & 4.0 \\
Land fraction cultivated for vegetable crops & 0.0188 & 0.046 \\
\hline
\end{tabular}

These values were used for all 2004 NESHAPs model runs and will be used until such time that another update is required. Lawrence Berkeley National Laboratory has also adopted these values for NESHAPs compliance. Changes to the agricultural parameters do not affect LLNL's dose to an individual (because the food is assumed to be either home-grown or imported), but the collective (population) dose is affected in the case of radionuclides that produce significant ingestion doses (e.g., tritium); LLNL's Livermore site collective dose increased by nearly a factor of three when these new values were used.

Some assumptions affecting ingestion dose also were changed for 2004. In the past, for individual dose it was assumed that $100 \%$ of vegetables and meat were homegrown and that $100 \%$ of milk was imported. Starting in 2004, it was more realistically assumed that $25 \%$ of the vegetables and meat are home-grown, while the remaining $75 \%$ of vegetables and meat and $100 \%$ of the milk is imported (i.e., free from LLNL-generated radioactivity). The result of this change is to reduce the dose to the individual to $40 \%$ of the dose calculated based on the previous more conservative assumptions. For collective dose, the assumption was changed from all food being locally grown to the urban default choice in CAP88-PC (in which 7.6\% of vegetables, $0 \%$ of milk, and $0.8 \%$ of meat are home-grown, with the balances obtained from the assessment area exposed to the released radioactivity). The assumption that the population exposed to Livermore releases eats an urban diet instead of a home-grown one decreases the collective dose attributable to tritium by about $10 \%$. 
The effect of the changes in agricultural parameter values and assumptions about diet affect the population dose somewhat differently depending on the magnitude of the source, the radionuclide in question and whether the source is a stack or a diffuse source. For the 2004 release of tritium from the Tritium Facility, the effect of both changes was to increase the collective dose by just over a factor of two. Ingestion is an important pathway for tritium, so the effects of these changes was much greater for tritium than for most radionuclides released from LLNL.

General Model Inputs: Attachment 1 details the key identifiers and input parameters for CAP88-PC model runs. These include building number; stack ID; isotope(s); emission rate in curies per year $\left(1 \mathrm{Ci}=3.7 \times 10^{10} \mathrm{~Bq}\right)$; and stack parameters, including height, diameter, and emission velocity.

Meteorological Data: All model runs used actual 2004 Livermore-site and Site 300 meteorological data, collected from the meteorological towers for each site. At these towers, wind speed and direction and temperature are sampled every one or two seconds, and are averaged into quarter-hour increments, time tagged, and computer recorded. The data are converted into a CAP88-PC input wind file using EPA guidelines.

Surrogate Radionuclides: CAP88-PC contains a library of 265 radionuclides; however, it does not contain all radionuclides in use at LLNL. As a consequence, use of surrogate radionuclides to estimate EDEs is sometimes necessary. The selection of a suitable surrogate is based upon several criteria, including metabolically similar behavior and similar modes of decay and decay energies of the radiation type of the isotope of interest. Once a surrogate is selected, the equivalent source term is adjusted by the product of the initial inventory of the isotope of interest and the ratio of the effective dose equivalent of the surrogate to that of the isotope of interest. In some cases, experimenters do not provide isotopic analyses of mixtures of radionuclides; they simply identify the radionuclides used as "gross alpha," "gross beta," "gross gamma," or "mixed fission products" (MFP). In these cases, for compliance modeling purposes ${ }^{239} \mathrm{Pu}$ is used as the surrogate for gross alpha, ${ }^{137} \mathrm{Cs}$ for gross gamma, and ${ }^{90} \mathrm{Sr}$ for gross beta and mixed fission products to provide conservative dose estimates.

Population Inputs: Population distributions centered on the two LLNL sites were updated for the 2003 modeling effort, and were used without change for the present report. These population distributions are based on the LandScan Global Population 2001 Database (Dobson, J. E., E. A. Bright, P. R. Coleman, R.C. Durfee, B. A. Worley, LandScan: A Global Population Database for Estimating Populations at Risk, Photogrammetric Engineering \& Remote Sensing Vol. 66, No. 7, July 2000, pp. 849-857; see also the Website http://www.ornl.gov/sci/gist/landscan/index.html). The population distributions were developed using the geographic information system software, ArcView $\odot$, to construct five equidistant radial sectors in each of the 16 
wind directions required by CAP88-PC. The population for each sector segment was determined by running code developed in the LandScan project and distributed with the LandScan Database. Key population centers affected by LLNL emissions are the nearby communities of Livermore and Tracy, and the more distant metropolitan areas of Oakland, San Francisco, and San Jose, as well as the San Joaquin Valley communities of Modesto and Stockton. Within the $80 \mathrm{~km}$ outer distance specified by DOE, there are 7.1 million residents included for the Livermore site collective dose determination, and 6.2 million for Site 300 .

Emission Source Terms: The source term for each emission source in the calculations was determined by one of three methods: For continuously monitored sources, the sampling data (curies released per unit time) for each radionuclide were used directly. For sources qualifying as "minor sources," ambient air monitoring data were used to gauge the maximum dose to the public from their emissions (see the subsection on "Compliance Demonstration for Minor Sources" in Section II). For unmonitored facilities or activities that do not fall in the category of minor sources, or that were new operations in the year covered by the report, potential emissions to air were estimated based on radionuclide usage inventories and facility knowledge, or the combined use of surveillance air monitoring and air dispersion modeling. Generally model runs for sources characterized by inventory data utilize "time factors" and EPA-specified physical state factors. Time factors adjust for the fact that a radionuclide may not always be in the same facility all year or may be encapsulated or enclosed for a substantial part of the year. The EPA-specified factors for potential release to air of materials in different physical states (solid, liquid, powder, or gas) are those stated in 40 CFR Part 61, Appendix D. If the material was an unconfined gas, or any material heated above $100^{\circ} \mathrm{C}$ (with exceptions noted in Table 7), then the factor 1.0 was used; for liquids and powders, $1.0 \times 10^{-3}$ was used; and for solids, $1.0 \times 10^{-6}$ was used.

The U.S. EPA has granted approval for LLNL to use alternative physical state factors for elemental uranium, various uranium compounds/alloys, and elemental plutonium. In 2003, LLNL requested general permission to use physical state factors based on actual physical form. The U.S. EPA did not grant this request, stating they are open to further discussion on this issue, but that such a change may require modification of the regulations. Table 7 provides the approved temperatures for application of the physical state factor for each material. 
In addition to physical state factors, emission control abatement factors (40 CFR 61, Appendix D) were used when applicable. Each HEPA filter stage was given a 0.01 abatement factor. (However, abatement factors were not used to evaluate compliance with the $0.1 \mathrm{mrem}[1 \mu \mathrm{Sv}]$ standard that determines the need for continuous monitoring at a facility.)

Table 7. List of materials exempted from the "treat as a gas above $100^{\circ} \mathrm{C}^{\prime}$ rule, and temperatures at which the various physical state factors apply.

\begin{tabular}{lcccc}
\hline Material & $\begin{array}{c}\text { Solid physical } \\
\text { state factor }\end{array}$ & $\begin{array}{c}\text { Liquid physical } \\
\text { state factor }\end{array}$ & $\begin{array}{c}\text { Gas physical } \\
\text { state factor }\end{array}$ & $\begin{array}{c}\text { Year } \\
\text { approved }\end{array}$ \\
\hline Elemental uranium & $<1100^{\circ} \mathrm{C}$ & Between $1100^{\circ} \mathrm{C}$ and $3000^{\circ} \mathrm{C}$ & $>3000^{\circ} \mathrm{C}$ & 1996 \\
Uranium/niobium alloy & $<1000^{\circ} \mathrm{C}$ & Between $1000^{\circ} \mathrm{C}$ and $3000^{\circ} \mathrm{C}$ & $>3000^{\circ} \mathrm{C}$ & 2001 \\
Uranium oxide & $<2000^{\circ} \mathrm{C}$ & Between $2000^{\circ} \mathrm{C}$ and $2500^{\circ} \mathrm{C}$ & $>2500^{\circ} \mathrm{C}$ & 2004 \\
Uranium nitride & $<2000^{\circ} \mathrm{C}$ & Between $2000^{\circ} \mathrm{C}$ and $2500^{\circ} \mathrm{C}$ & $>2500^{\circ} \mathrm{C}$ & 2004 \\
Uranium carbide & $<2000^{\circ} \mathrm{C}$ & Between $2000^{\circ} \mathrm{C}$ and $2500^{\circ} \mathrm{C}$ & $>2500^{\circ} \mathrm{C}$ & 2004 \\
Elemental plutonium & $<600^{\circ} \mathrm{C}$ & Between $600^{\circ} \mathrm{C}$ and $3000^{\circ} \mathrm{C}$ & $>3000^{\circ} \mathrm{C}$ & 2001 \\
\hline
\end{tabular}

Site-Wide Maximally Exposed Individual: For LLNL to comply with the NESHAPs regulations, the LLNL site-wide maximally exposed individual cannot receive an EDE greater than $10 \mathrm{mrem} / \mathrm{y}(100 \mu \mathrm{Sv} / \mathrm{y})$. The site-wide maximally exposed individual (SW-MEI) is defined as the hypothetical member of the public at a single residence, school, business, church, or other such facility, who receives the greatest LLNL induced EDE from the combination of all evaluated radionuclide source emissions, as determined by modeling.

At the Livermore site, the SW-MEI for 2004 was found, as usual, to be located at the UNCLE Credit Union, about $10 \mathrm{~m}$ outside the controlled eastern fence line of the site, but about $10 \mathrm{~m}$ within the perimeter of the site property, as shown in Figure 3 . At Site 300, the 2004 SW-MEI was located, as in the past several years, at the boundary with the Carnegie State Vehicle Recreation Area, managed by the California Department of Parks and Recreation, approximately $3.2 \mathrm{~km}$ south southeast of the firing table at Building 851, as shown in Figure 4.

Doses to the SW-MEIs were evaluated for each source and then totaled for sitespecific evaluations against the $10 \mathrm{mrem} / \mathrm{y}(100 \mu \mathrm{Sv})$ dose standard (see "Total Dose to Site-Wide Maximally Exposed Individuals" in Section IV). 


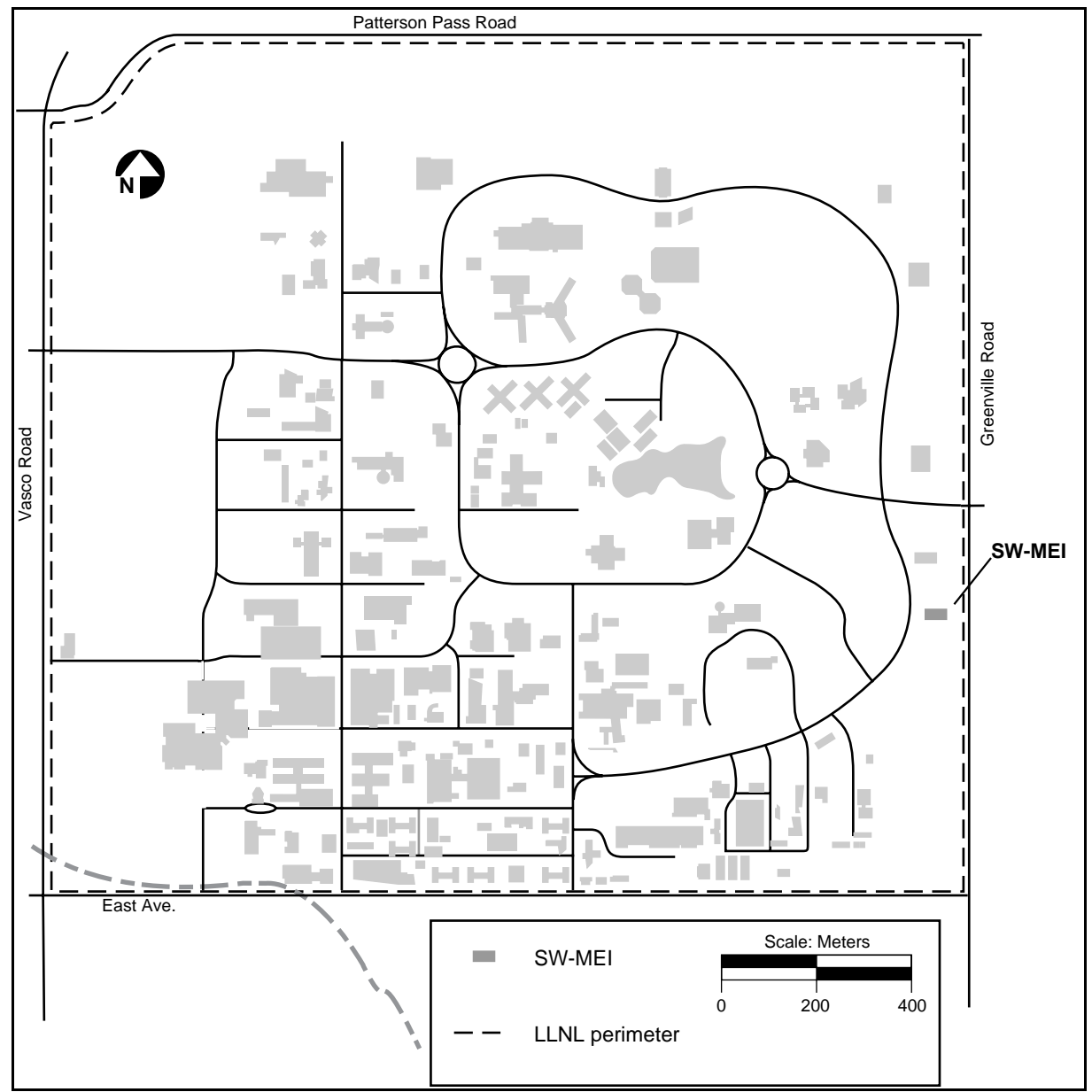

Figure 3. Location of Site-Wide Maximally Exposed Individual (SW-MEI) at the Livermore site, 2004.

Maximally Exposed Public Individual: To assess compliance with the EPA requirement for continuous monitoring of a release point (potential dose greater than $0.1 \mathrm{mrem} / \mathrm{y}[1.0 \mu \mathrm{Sv} / \mathrm{y}]$ ), emissions must be individually evaluated from each point source to determine the dose to the maximally-exposed individual (MEI) member of the public. The location of the MEI is generally different for each emission point, and must occur at a location of unrestricted public access. Typically this location is a point on the site perimeter, prompting the MEI dose to be referred to as the maximum "fence line" dose. However the off-site maximum dose can occur some distance beyond the perimeter, e.g., when a facility stack is close to the perimeter. Modeling calculations show that ground level concentrations of radionuclides can be expected to reach maximum values beyond the LLNL boundaries for releases from the DWTF stack on the Livermore site and dispersals from open-air explosives experiments conducted at Site 300. As stipulated by the 
regulations in 40 CFR Section 61.93 (b)(4)(ii), modeling for evaluation of the need for continuous monitoring must assume unabated emissions (i.e., no credit can be taken for emission abatement devices, such as filters). Model run documentation typically includes evaluation of the dose to the MEI, specification of emission abatement factors (in place but not credited for the required monitoring evaluation), and the distance and direction to the LLNL fence line point where (or beyond which) the MEI is located; see the Attachment.

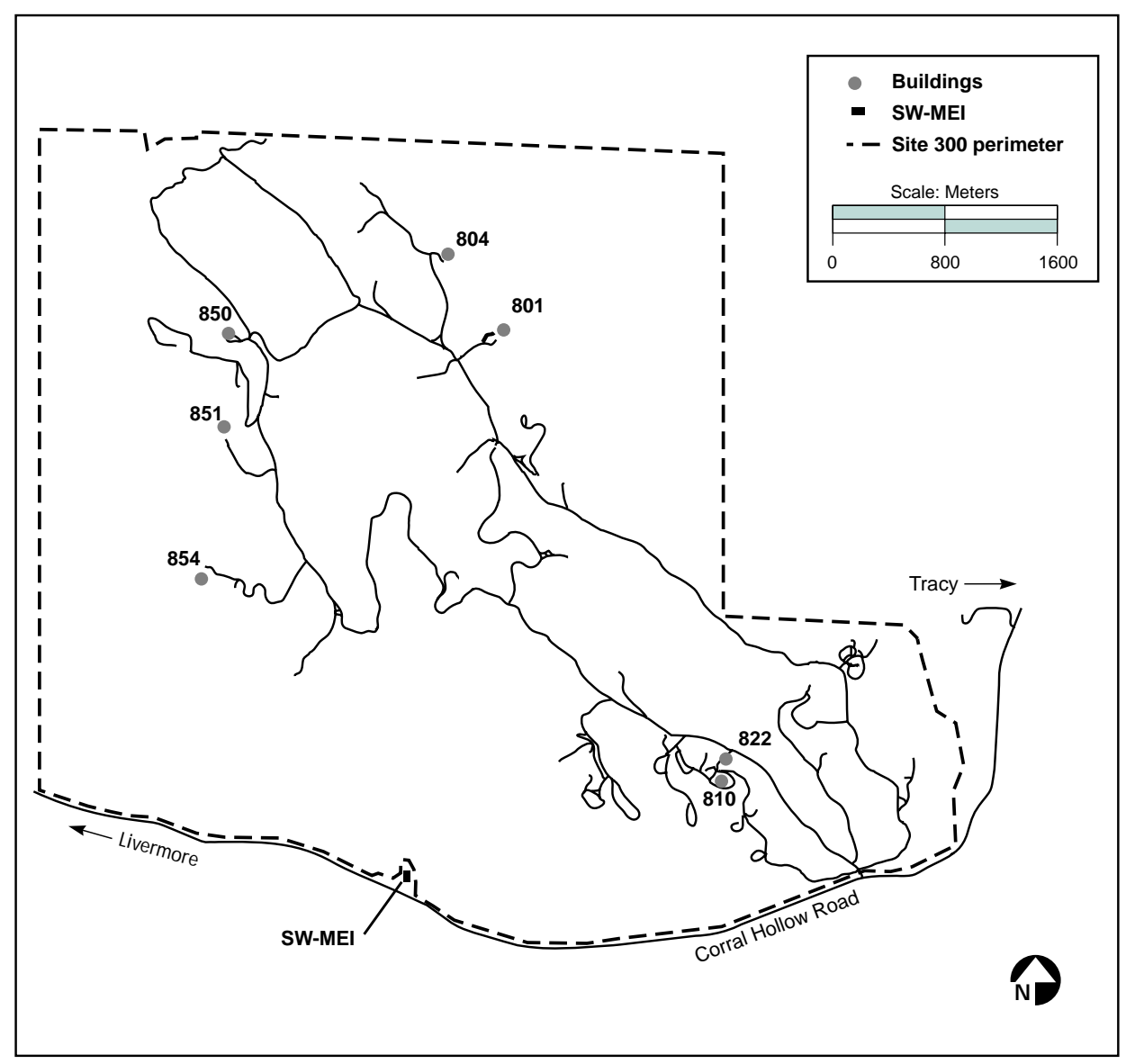

Figure 4. Location of Site-Wide Maximally Exposed Individual (SW-MEI) at Site 300, 2004. 


\section{SECTION IV. Results of 2004 Radiological Dose Assessment}

This section summarizes the doses to the most exposed public individuals from LLNL operations in 2004, shows the comparison to previous years, presents the potential doses to the populations residing within $80 \mathrm{~km}$ of either the Livermore site or Site 300, and summarizes LLNL's compliance with 40 CFR 61, Subpart H (61.93).

\section{Total Dose to Site-Wide Maximally Exposed Individuals}

The total dose to the Livermore site SW-MEI from operations in 2004 was 0.0079 mrem $(0.079 \mu \mathrm{Sv})$. Of this, $0.0021 \mathrm{mrem}(0.021 \mu \mathrm{Sv})$ or $27 \%$ was contributed by point sources, while diffuse emissions accounted for $0.0058 \mathrm{mrem}(0.058 \mu \mathrm{Sv})$ or $73 \%$ of the total. The point source dose includes Tritium Facility HT emissions modeled as HTO, as directed by EPA Region IX. (See "Modeling Dose from Tritium" in Section VII and the Attachment for changes (decreases) in the dose from tritium when this assumption is not used.)

This SW-MEI dose is the lowest reported for the Livermore site since 1990, when NESHAPs reporting commenced. The main factors leading to the low dose were a relatively low level of operations and emissions from the Tritium Facility (Building 331), reorganization of operations of the Radioactive and Hazardous Waste Management Division (with more potential releases of radiation directed through a HEPA-filtered and continuously-monitored 30-m stack [see "Changes in Operations and Facilities ..." in Section VI], and a readjustment of the food intake (ingestion) assumptions regarding the Livermore site, as used in CAP88-PC model runs [see "Land Use and Agricultural Inputs" in Section III].

The total dose to the Site 300 SW-MEI from operations in 2004 was 0.026 mrem $(0.26 \mu \mathrm{Sv})$. Point source emissions from firing table explosives experiments accounted for $97 \%$ of this total, while about $3 \%$, was contributed by diffuse sources.

Table 8 shows the facilities or sources that collectively accounted for $90 \%$ or more of the doses to the SW-MEI for the Livermore site and Site 300 in 2004. Although LLNL has more than 150 sources with potential for releasing radioactive material to air according to NESHAPs prescriptions, most are very minor. Each year, nearly the entire radiological dose to the public from LLNL operations comes from no more than a dozen sources. 
Table 8. Ranked list of facilities or sources whose emissions collectively accounted for at least 90\% of the SW-MEI doses for the Livermore site and Site 300 in 2004.

\begin{tabular}{llc}
\hline Facility (Source Category) & $\begin{array}{c}\text { CAP88-PC } \\
\text { Dose in } \\
\text { mrem/y }\end{array}$ & $\begin{array}{c}\text { CAP88-PC } \\
\text { Percentage Contribution to } \\
\text { Total Dose }\end{array}$ \\
\hline Livermore site & & \\
Building 612 Yard (diffuse source) & 0.0053 & $67 \%$ \\
Building 331 stacks (point source) & 0.0014 & $18 \%$ \\
DWTF stack (point source) & 0.00069 & $8.8 \%$ \\
\hline Site 300 & & \\
Bldg. 851 Firing Table (point source) & 0.025 & $97 \%$ \\
Soil resuspension (diffuse source) & 0.00086 & $3 \%$ \\
\hline
\end{tabular}

Table 9 compares 2004 doses with those of previous years. No diffuse emissions were reported at Site 300 for years before 1993, so comparison of total Site 300 dose can only be made for 1993 and later. In addition, diffuse source doses were not reported separately from the total dose for the Livermore site for 1990 and 1991.

\section{Doses from Unplanned Releases}

There were no unplanned atmospheric releases of radionuclides at the Livermore site or Site 300 in 2004.

\section{Population Doses}

Population doses, or collective EDEs, for both LLNL sites were calculated out to a distance of $80 \mathrm{~km}$ in all directions from the site centers using CAP88-PC. This air dispersion and dose assessment model evaluates the four principal exposure pathways: ingestion through food and water consumption, inhalation, air immersion, and irradiation by contaminated ground surface.

The CAP88-PC result for potential collective dose attributed to 2004 Livermore-site operations was 1.0 person-rem (0.01 person-Sv); the corresponding collective EDE from Site 300 operations was 3.9 person-rem ( 0.039 person-Sv). The values for the Livermore site collective doses from tritium are higher than in 2003 even though the release rates of tritium were much lower for 2004 because of the new assumptions about agricultural density in California. Nevertheless, these values are both quite small and within the normal range of variation seen from year to year. By way of comparison, the collective dose to the roughly 7 million people within $80 \mathrm{~km}$ of LLNL's two sites from exposure to the average level of natural background radioactivity in the United States is $2.1 \times 10^{6}$ person-rem ( $2.1 \times 10^{4}$ person-Sv). 
LLNL NESHAPs Report 2004

Table 9. Doses (in mrem) calculated for the Site-Wide Maximally Exposed Individual (SW-MEI) for the Livermore site and Site 300, 1990 to 2004.

\begin{tabular}{|c|c|c|c|}
\hline Year & Total Dose & Point Source Dose & Diffuse Source Dose \\
\hline \multicolumn{4}{|l|}{ Livermore site } \\
\hline 2004 & $0.0079^{a}$ & $0.0021^{\mathrm{a}}$ & 0.0058 \\
\hline 2003 & $0.044^{\mathrm{a}}$ & $0.024^{\mathrm{a}}$ & 0.020 \\
\hline 2002 & $0.023^{\mathrm{a}}$ & $0.010^{\mathrm{a}}$ & 0.013 \\
\hline 2001 & $0.017^{a}$ & $0.0057^{a}$ & 0.011 \\
\hline 2000 & $0.038^{\mathrm{a}}$ & $0.017^{\mathrm{a}}$ & 0.021 \\
\hline 1999 & $0.12^{\mathrm{a}}$ & $0.094^{\mathrm{a}}$ & 0.028 \\
\hline 1998 & $0.055^{\mathrm{a}}$ & $0.031^{\mathrm{a}}$ & 0.024 \\
\hline 1997 & 0.097 & 0.078 & 0.019 \\
\hline 1996 & 0.093 & 0.048 & 0.045 \\
\hline 1995 & 0.041 & 0.019 & 0.022 \\
\hline 1994 & 0.065 & 0.042 & 0.023 \\
\hline 1993 & 0.066 & 0.040 & 0.026 \\
\hline 1992 & 0.079 & 0.069 & 0.010 \\
\hline 1991 & 0.234 & $-b$ & $-b$ \\
\hline 1990 & 0.240 & $-b$ & $-b$ \\
\hline \multicolumn{4}{|l|}{ Site 300} \\
\hline 2004 & 0.026 & 0.025 & 0.00086 \\
\hline 2003 & 0.017 & 0.017 & 0.00034 \\
\hline 2002 & 0.021 & 0.018 & 0.0033 \\
\hline 2001 & 0.054 & 0.050 & 0.0037 \\
\hline 2000 & 0.019 & 0.015 & 0.0037 \\
\hline 1999 & 0.035 & 0.034 & 0.0012 \\
\hline 1998 & 0.024 & 0.019 & 0.005 \\
\hline 1997 & 0.020 & 0.011 & 0.0088 \\
\hline 1996 & 0.033 & 0.033 & 0.00045 \\
\hline 1995 & 0.023 & 0.020 & 0.003 \\
\hline 1994 & 0.081 & 0.049 & 0.032 \\
\hline 1993 & 0.037 & 0.011 & 0.026 \\
\hline 1992 & 0.021 & 0.021 & $-c$ \\
\hline 1991 & 0.044 & 0.044 & $-c$ \\
\hline 1990 & 0.057 & 0.057 & $-c$ \\
\hline
\end{tabular}

a The dose includes HT emissions modeled as HTO as directed by EPA Region IX. EPA Region IX acknowledges that such modeling results in an overestimation of the dose. This methodology is used for purposes of compliance.

b Diffuse source doses were not reported separately from the total dose for the Livermore site for 1990 and 1991.

c No diffuse emissions were evaluated at Site 300 for years before 1993. 
The collective doses from LLNL are high relative to many other DOE facilities because of the large populations lying within $80 \mathrm{~km}$ of the Livermore Site and Site 300. Although the collective dose may be the same, a large dose to a small number of people is not equivalent to a small dose to many people. A better way to present the collective doses from LLNL operations is to disaggregate them into categories of individual dose, which demonstrates the tiny doses received by most of the population.

For the Livermore Site, population doses from stack and area releases of tritium may be broken down as shown in Table 10.

Table 10. Disaggregations of collective dose for the Livermore site, 2004.

\begin{tabular}{lcc}
\hline $\begin{array}{c}\text { Individual dose } \\
\text { mrem/y }\end{array}$ & $\begin{array}{c}\text { Collective dose } \\
\text { person-rem/y }\end{array}$ & $\begin{array}{c}\text { Percent total } \\
\text { collective dose }\end{array}$ \\
\hline 0.001 to 0.01 & 0.00271 & $0.272 \%$ \\
0.0001 to 0.001 & 0.0346 & $3.46 \%$ \\
0.00001 to 0.0001 & 0.934 & $93.4 \%$ \\
0.000001 to 0.00001 & 0.0283 & $2.84 \%$ \\
Total & 1.0 & $100 \%$ \\
\hline
\end{tabular}

It can be seen in the table above that the individuals that make up more than $95 \%$ of the population receive less than $0.0001 \mathrm{mrem} / \mathrm{y}(0.001 \mu \mathrm{Sv} / \mathrm{y})$.

Collective doses can be broken down similarly for the shots from the Building 851 Firing Table at Site 300, as shown in Table 11. In this case individuals that make up $98 \%$ of the population receive less than $0.0001 \mathrm{mrem} / \mathrm{y}(0.001 \mu \mathrm{Sv} / \mathrm{y}) \mathrm{mrem} / \mathrm{y}$.

Table 11. Disaggregations of collective dose for Site 300, 2004.

\begin{tabular}{ccc}
\hline $\begin{array}{c}\text { Individual dose } \\
\text { mrem/y }\end{array}$ & $\begin{array}{c}\text { Collective dose } \\
\text { person-rem/y }\end{array}$ & $\begin{array}{c}\text { Percent total } \\
\text { collective dose }\end{array}$ \\
\hline 0.001 to 0.01 & 0 & $0 \%$ \\
0.0001 to 0.001 & 0.0753 & $1.96 \%$ \\
0.00001 to 0.0001 & 1.39 & $36.2 \%$ \\
0.000001 to 0.00001 & 2.38 & $61.8 \%$ \\
Total & 3.85 & $100 \%$ \\
\hline
\end{tabular}




\section{Compliance with 40 CFR 61 Subpart H (61.93)}

Calculations of effective dose equivalents for Livermore-site and Site 300 facilities having the potential to release radioactive material to the atmosphere were found to be well below the 10 mrem $(100 \mu \mathrm{Sv})$ NESHAPs dose standard for dose to the mostexposed individual members of the public. Tritium accounted for $96 \%$ of the Livermore-site calculated dose, while at Site 300 practically the entire calculated dose was due to the isotopes ${ }^{238} \mathrm{U},{ }^{235} \mathrm{U}$, and ${ }^{234} \mathrm{U}$, in depleted uranium.

In 2004, there were six buildings (Buildings 235, 251, 331, 332, 491, and 695/696) at the Livermore site and one (Building 801A, the Contained Firing Facility) at Site 300 that had radionuclide air effluent monitoring systems. (Buildings 695 and 696 in the DWTF complex vent through a common stack.) These buildings are listed, along with the number of samplers, the types of samplers, and the analytes of interest, in Table 2.

LLNL remains committed to monitoring stack effluent air from its Tritium Facility (Building 331), Plutonium Facility (Building 332), Decontamination and Waste Treatment Facility (Building 695/696), Contained Firing Facility (Building 801A), and the seismically hardened area of its Heavy Element Facility (Building 251). In addition, other facilities are continuously monitored, as necessary, based on evaluations of potential emissions without control devices, as in the case of Building 235, or where classification or other issues prevent a usage-inventory-based evaluation. 


\section{SECTION V. Certification}

I certify under penalty of law that this document and all attachments were prepared under my direction or supervision in accordance with a system designed to assure that qualified personnel properly gather and evaluate the information submitted. Based on my inquiry of the person or persons who manage the system, or those persons directly responsible for gathering the information, the information submitted is, to the best of my knowledge and belief, true, accurate, and complete. I am aware that there are significant penalties for submitting false information, including the possibility of fine and imprisonment for knowing violations.

Name: $\quad$ William A. Bookless

Associate Director

Safety and Environmental Protection

Lawrence Livermore National Laboratory

7000 East Avenue, L-668

Livermore, CA 94550

Signature:

William A. Bookless

Date:

I certify under penalty of law that I have personally examined and am familiar with the information submitted herein, and based on my inquiry of those individuals immediately responsible for obtaining the information, I believe that the submitted information is true, accurate, and complete. I am aware that there are significant penalties for submitting false information, including the possibility of fine and imprisonment. See 18 U.S.C. 1001.

Name: Phillip Hill

Technical Deputy

Safety and Environmental Programs

U.S. Department of Energy

7000 East Avenue, L-293

Livermore, CA 94550

Signature: Date:

Phillip Hill 


\section{SECTION VI. Supplemental Information on NESHAPS Compliance and QA/QC Activities}

\section{Use of Surveillance Air Monitoring in Demonstrating NESHAPs Compliance for LLNL's Numerous Minor Sources}

As noted earlier in Section II under the heading "Compliance Demonstration for Minor Radiological Sources," the assessment of 2004 operations marked the second year of implementing a new approach approved by EPA for evaluating NESHAPs compliance of LLNL's many minor sources of radiological releases to air. As in 2003, this greater reliance on surveillance air monitoring data and less on radiological usage inventories in 2004 resulted in considerable simplification and savings in time and expense.

\section{Periodic Confirmatory Measurements}

Results of NESHAPs periodic confirmatory measurements serve to support or confirm two objectives: (1) that those operations not continuously monitored do not, in fact, need to be continuously monitored, and (2) that radionuclide usageinventory-based estimates of emissions and their corresponding doses are conservative.

In 2004, periodic confirmatory sampling was conducted for a period of 18 days from the Decontamination and Waste Treatment Facility (DWTF) stack venting air from Buildings 695 and 696. The sampling focused specifically on tritium emissions using a glycol capture mechanism that collects tritium in the form of HTO. This method of collection satisfies the principles of measurement stated in 40 CFR 61 Appendix B, Method 114. The tritium collector (manufactured by SDEC France Inc. Model HAGUE 7000) uses a two stage glycol impinging process to capture any HTO present. After the sampled air passes through the second stage impinger, it is directed through a palladium catalyst where oxidation of any HT in the sample takes place and converts HT to HTO, which is then collected in the third and fourth stage impingers. This type of sampling quantifies the amount of tritium for both species HT and HTO using liquid scintillation analysis performed by the Radiological Measurements Laboratory (RML) in LLNL's Hazards Control Department.

Operations at the DWTF during the 18 days of monitoring released a total of $0.21 \mathrm{Ci}$ $\left(7.8 \times 10^{9} \mathrm{~Bq}\right)$ of tritium. Of this, $0.12 \mathrm{Ci}\left(4.4 \times 10^{9} \mathrm{~Bq}\right)$ was released as tritiated water (HTO). The remaining tritium released, $8.7 \times 10^{-2} \mathrm{Ci}\left(3.2 \times 10^{9} \mathrm{~Bq}\right)$, was elemental tritium gas (HT). 
To evaluate the need for continuous monitoring, the total tritium release over a full year was linearly projected to be $4.3 \mathrm{Ci}\left(1.6 \times 10^{11} \mathrm{~Bq}\right)$, and the modeled total dose to the hypothetical maximally exposed member of the public (modeling HT emissions as HTO as required by EPA) was $3.6 \times 10^{-4} \mathrm{mrem} / \mathrm{y}\left(3.6 \times 10^{-3} \mu \mathrm{Sv} / \mathrm{y}\right)$, more than 270 times lower than the level requiring monitoring.

\section{Implementation of the ANSI/HPS N13.1-1999 Stack Sampling Standard for a 2004 New Activity}

In 2004 a new activity, the TRU Mover, required Subpart H compliant continuous monitoring of the air effluent for gross alpha and gross beta particulate in accordance with the performance measures called for in ANSI/HPS N13.1-1999: "Sampling and Monitoring Releases of Airborne Radioactive Substances from the Stacks and Ducts of Nuclear Facilities." The TRU Mover, a specially designed multiple-stage HEPAfiltered glovebox for repackaging of 55-gallon drums containing transuranic (TRU) waste, was supplied by the Washington Group International. LLNL successfully designed, fabricated, and validated the air effluent system as described in ANSI N13.1 - 1999 RHWM TRU Mover Air Effluent Design and Performance Report (K. Wilson, 2004). The resulting ventilation and sampling system conforms to the compliance requirements of NESHAPs, Title 40 CFR 61 Subpart $\mathrm{H}$.

\section{NESHAPs Quality Assurance (QA) Program}

The LLNL NESHAPs quality assurance program is a multi-organizational effort. Its major components are the LLNL facilities/ programs that have continuous stack effluent monitoring systems; the Radiological Measurements Laboratory (RML) and the Analytical Laboratory (AL), both in the Hazards Control Department (HCD); and the Environmental Protection Department (EPD). To coordinate the activities of these organizations, NESHAPs Agreement of Roles and Responsibilities (NARRs) documents are in place between EPD and the facilities and/or programs and HCD. NARRs formalize responsibilities and obligations of the organizations regarding many tasks for the air effluent sample network. Tasks that are addressed in the NARRs include air sampler design and installation, procedures and their implementation, sampling, sample analysis and tracking, maintenance and repair of sampling systems, guidance on regulatory requirements, documentation of the sampling network, reporting, and the archival of records.

The NESHAPs quality assurance project plan is included in the "NESHAPs Compliance Guidance Document and Quality Assurance Project Plan (G. Gallegos, EMP-NS-S, 2004). This document recites the key elements of the NESHAPs Quality Assurance Project Plan (QAPP) as specifically prescribed by 40 CFR 61, App. B, Method 114. Because LLNL's NESHAPs quality assurance activities are conducted by two LLNL departments, EPD and HCD, the documentation for the elements of a complete quality assurance project plan (QAPP) are independently maintained by 
these organizations. The NESHAPs QAPP presents a cross-walk between the requirements of a complete QAPP, the documents that meet those requirements, and the responsible organization.

A general overview of these requirements and the responsible organizations is as follows. EPD is responsible for an annual assessment and demonstration of LLNL's compliance with NESHAPs, as documented in the present report. EPD's Terrestrial and Atmospheric Monitoring and Modeling (TAMM) Group is responsible for environmental monitoring; calibration, inspection, and maintenance of all stack sampling activities; air dispersion and dose assessment modeling; assessment (in cooperation with Laboratory Program personnel) of usage of radioactive materials and their potential releases to air in operations throughout the Laboratory; record keeping; and reporting to EPA and DOE to demonstrate the Laboratory's compliance with NESHAPs.

Hazards Control Department (HCD) is responsible for conducting the stack sampling and radiological analyses. HCD is also responsible for assuring the quality of the samples, sample tracking, and analytical quality control.

The LLNL Assurance Review Office periodically audits EPD and HCD activities.

\section{Evaluation of New Radiological Projects}

The TAMM Group is informed of proposed new operations, and modified operations where significant changes in radiological usage inventories occur, by several mechanisms. These include reviews of National Environmental Policy Act (NEPA) documentation, Integration Worksheets, Occupational Safety Plans (describing facility-specific safety procedures and plans), and knowledge derived from participation on EPD's Environmental Support Teams (ESTs). In the NESHAPs context, the EST representatives from the TAMM Group and the Environmental Operations Group (EOG) have primary responsibilities. Written communications between NESHAPs analysts and project principal investigators, including records of model runs carried out to evaluate the need for monitoring of radiological releases and the need to obtain permission from EPA to start up operations, are retained in TAMM Group for at least the period of time specified in 40 CFR 61 Subpart H.

\section{Quality Control (QC) for 2004 Air Dispersion and Dose Assessment Model Runs}

Under the new protocol mentioned in the leading paragraph of this Section VI, the only radiological facilities or projects providing an accounting by means of radionuclide inventories were ones commencing operation in 2004, or unmonitored point source releases that contributed significantly in 2004 to the dose to the public. 
The former underwent NESHAPs evaluation in which NEPA or other documents such as Integration Work Sheets and Occupational Safety Plans were examined prior to start-up of operations, and CAP88-PC model runs were performed to determine the maximum potential doses to the public from the activities. The latter were 12 explosives experiments conducted in 2004 at Firing Table 851 at Site 300. Both the input data and model runs for all 12 explosives experiments were independently checked and validated.

Model runs were performed for about two dozen sources in the 2004 assessment, including the activities mentioned above and two stack-monitored facilities that released tritium to air: the Tritium Facility and Decontamination and Waste Treatment Facility (DWTF). More than half of all model runs were checked independently. Facility personnel reviewed and concurred with source-term data inferred by the NESHAPs analysts for both the Building 331 Outside waste accumulation area and the DWTF stack.

Copies of individual model runs, including input parameters and resultant calculated doses, are archived in the records kept by TAMM Group.

Based on these QC efforts, we believe that the data, results, and conclusions presented in this report meet EPD's quality assurance objectives.

\section{Changes in Operations and Facilities for Radioactive and Hazardous Waste Management}

A new state-of-the-art, integrated facility for storing and processing hazardous, radioactive, and mixed wastes, LLNL's DWTF, opened for operation in September 2003. Five buildings comprise the facility: Building 695 (liquid waste processing), Building 696 (solid waste processing and storage), and three others (see the report

"Recent Advances in the Environmental Protection Department," UCRL-BR-208053, Dec. 2004, pp. 15-17, for a description of the facility). Building 695 and Building 696 share a complex ventilation system that connects to the atmosphere through DWTF's HEPA-filtered, continuously monitored (for radioactive particles) 30-m stack.

From a NESHAPs perspective, a consequence of the new facility's operation in 2004 was a significant reduction in potential and actual radiological releases to air from Radioactive and Hazardous Waste Management (RHWM) Division operations, and considerable improvement (compared to the previously employed inventory method) in our knowledge of the amount of the potentially releasable quantities. In particular, Building 695 now houses most of the higher-dose activities attributed to RHWM in recent years. These include the evaporator, Dorr-Oliver filtration unit, and stabilization unit, all of which were previously in Building 514, and the waste 
verification laboratory that was located in Rooms 101 and 102 of Building 612. Regarding maximum potential dose to the public, these activities in 2002 and 2003, for example, contributed approximately 0.003 mrem/y $(0.03 \mu \mathrm{Sv})$ to the SW-MEI dose. This number dropped by approximately a factor of four for these operations in 2004 , to a level of 0.0007 mrem $(0.007 \mu \mathrm{Sv})$.

\section{SECTION VII: Supplementary Information on Radiological Dose Assessment for 2004}

\section{Livermore Site Principal Diffuse Sources}

The dose evaluations for diffuse sources at the Livermore site in 2004 required several different modeling approaches. Building 331 WAA and Building 612 Yard emissions estimates were based on facility personnel knowledge and "back calculations" (in which the source terms in model runs were adjusted to reproduce the concentrations determined from environmental surveillance air monitoring data). The dose in each of these cases was calculated using CAP88-PC. Air surveillance monitoring data for plutonium from an ambient air monitor at the location of the SW-MEI was used directly (sans model run) to evaluate the dose from historical plutonium contamination in the Southeast Quadrant.

\section{Building 331 Outside Yard Waste Accumulation Area}

As the Tritium Facility (Building 331) conducts operations, tritium-contaminated equipment and material slated for disposal are packaged in a waste accumulation and storage area, removed from the building to an outside storage container, and finally sent to Radioactive and Hazardous Waste Management Division (RHWM) facilities. During 2004, outgassing from such waste released an estimated 0.7 Ci (2.6 $\times 10^{10} \mathrm{~Bq}$ ) of tritium to the atmosphere outside Building 331. This amount was derived from a combination of environmental surveillance monitoring data and air dispersion back-calculation, and agreed with estimates based on process and facility knowledge. Its release was modeled in CAP88-PC as a $1 \mathrm{~m}^{2}$ area source, leading to a calculated 2004 dose to the SW-MEI of $1.7 \times 10^{-4}$ mrem $\left(1.7 \times 10^{-3} \mu \mathrm{Sv}\right)$. A dose 0.89 times this amount was calculated using the NEWTRIT model with air concentrations calculated by CAP88-PC (see "Modeling dose from tritium" later in this section).

\section{Building 612 Yard}

The Building 612 Yard is a potential source of diffuse emissions of tritium. This area is dedicated to hazardous waste, radioactive waste, and mixed waste management activities. The yard consists of several areas where waste containers are stacked outdoors. Several of these containers outgas tritium. A surveillance air monitor designated B624 has been placed in the Building 612 Yard to provide continuous measurements of tritium in air near this source. The mean annual concentration of 
tritium in air for 2004 in this area was $67.8 \mathrm{pCi} / \mathrm{m}^{3}\left(2.5 \mathrm{~Bq} / \mathrm{m}^{3}\right)$. These data were used to calculate the total tritium emissions from the area, using a conservative approach that assumed the source to be $60 \mathrm{~m}$ south-southwest of the air sampler. With this assumption, a diffuse source emission of $3.2 \mathrm{Ci} / \mathrm{y}\left(1.2 \times 10^{11} \mathrm{~Bq} / \mathrm{y}\right)$ was required to produce the concentrations measured at the air sampler. This source term produced a CAP88-PC-calculated 2004 dose to the SW-MEI from the Building 612 Yard of $5.3 \times 10^{-3} \mathrm{mrem}\left(5.3 \times 10^{-2} \mu \mathrm{Sv}\right)$. As in the preceding section, a dose 0.89 times this amount was calculated using the NEWTRIT model with air concentrations calculated by CAP88-PC. (Under our presently used ingestion assumptions relating to agriculture and land use in the vicinity of LLNL, the ratio of dose predicted by NEWTRIT to that by CAP88-PC is always 0.89 for a source releasing only HTO.)

\section{Southeast Quadrant}

The Southeast Quadrant of the Livermore site has elevated levels of plutonium in the surface soil (from historic waste management operations) and air (from resuspension). A high volume air particulate sampler is located adjacent to the UNCLE Credit Union (the location of the SW-MEI) to monitor the plutonium levels in this area. Monitoring data from this air sampler were used as a direct measurement of potential dose via the air pathway. The median annual concentration of ${ }^{239+240} \mathrm{Pu}$ (the analytical technique used, namely alpha spectroscopy, does not distinguish between ${ }^{239} \mathrm{Pu}$ and ${ }^{240} \mathrm{Pu}$ ) in air was $1.2 \times 10^{-19}$ $\mathrm{Ci} / \mathrm{m}^{3}\left(4.6 \times 10^{-9} \mathrm{~Bq} / \mathrm{m}^{3}\right)$. Using the dose conversion factor of $3.08 \times 10^{5} \mathrm{mrem} / \mu \mathrm{Ci}$ $\left(8.32 \times 10^{-5} \mathrm{~Sv} / \mathrm{Bq}\right)$ from Federal Guidance Report No. 11, EPA-520/1-88-020, U.S. Environmental Protection Agency (1988) for ${ }^{239} \mathrm{Pu}$ and ${ }^{240} \mathrm{Pu}$, and the standard man breathing rates of $8400 \mathrm{~m}^{3} / \mathrm{y}$, the dose was determined to be $3.2 \times 10^{-4}$ mrem $(3.2 \mathrm{x}$ $\left.10^{-3} \mu \mathrm{Sv}\right)$ for 2004 .

\section{Site 300 Principal Diffuse Sources}

Diffuse sources at Site 300 predominantly feature the radioisotopes in depleted uranium, with trace amounts of tritium being the only other radiological component of concern as having potential for release to air.

\section{Tritium Evaporation and Migration at Site 300}

Tritium gas and solids containing tritium $\left(\mathrm{Li}^{3} \mathrm{H}\right)$ were components of explosives assemblies tested on the firing tables during experiments in years past. Most of the gaseous tritium escaped to the atmosphere during the tests, but some of the solid $\mathrm{Li}^{3} \mathrm{H}$ remained as residue in the firing table gravel. Rainwater and dust-control rinse water percolated through the gravel, causing the tritium to migrate into the subsurface soil and, in some cases, eventually to the ground water. Tritium contaminated gravel was removed from the firing tables in 1988 and disposed in the Pit 7 landfill. Tritium in landfills, firing table soils, and ground water are potential sources of diffuse emissions of tritium to the atmosphere at Site 300. LLNL personnel maintain an air tritium sampler at a perimeter location at Site 300, and 
doses from diffuse tritium sources may be estimated based on the monitoring data for that sampling location. For the calendar year 2004, all measurements in ambient air at the Site 300 perimeter location were at or near the minimum detection limit of the analytical method (about $0.65 \mathrm{pCi}[25 \mathrm{mBq}] / \mathrm{m}^{3}$ ).

\section{Resuspension of Depleted Uranium in Soil at Site 300}

Depleted uranium has been used as a component of explosives test assemblies over many years. It remains as a residue in surface soils, especially near the firing tables. Because surface soil is subject to resuspension by the action of wind, rain, and other environmental disturbances, the collective effects of surface soil uranium residuals on off-site doses were evaluated.

A model was developed to distinguish between the contribution to measured uranium activities arising from naturally occurring uranium (NU) and that from depleted uranium (DU) contributed by LLNL operations. (A derivation of the model was presented in Gallegos et al., LLNL NESHAPs 1995 Annual Report, UCRL-ID113867-96, June 1996. We base our dose estimate for resuspended depleted uranium (DU) on the measured environmental surveillance monitoring total concentration in air of uranium-238, subtracting out the part contributed by NU, from the following equation:

$$
\mu=\frac{0.00726-0.99274 \frac{M(C U-235)}{M(C U-238)}}{0.00526 \frac{M(C U-235)}{M(C U-238)}+0.00526}
$$

where $\mu$ is the fraction (by weight) of uranium contributed by operations, $\mathrm{CU}$ is composite uranium (both DU and NU), M(CU-235) the mass of U-235 in the composite (measured) uranium, and M(CU-238) the mass of U-238 in the composite (measured) uranium.

For 2004, all eight air-particulate monitors at Site 300 were used to determine the annual-average concentrations of isotopes U-238 and U-235. (Measurements obviously affected by 2004 explosives tests were excluded; doses are explicitly calculated for explosives tests). These site-average values gave an estimate of $8.6 \mathrm{x}$ $10^{-4}$ mrem $\left(8.6 \times 10^{-3} \mu \mathrm{Sv}\right)$ for the SW-MEI dose resulting from resuspension of DU in soil for 2004 . 


\section{Modeling Dose from Tritium}

To evaluate dose from tritium releases to air, we use the EPA-sanctioned CAP88-PC code. Its tritium model calculates dose from inhalation, skin absorption, and ingestion of tritium only in its tritiated water vapor form (HTO). Doses from tritiated gas (HT) or organically bound tritium (OBT) are not calculated. CAP88-PC's tritium model is based on the specific activity model, which assumes that the tritium-to-hydrogen ratio in body water is the same as in air moisture. Because the specific activity model is linked in CAP88-PC with relatively high dose coefficients for HTO, the model's dose predictions generally err on the high side.

Inhalation doses from unit concentration of HT in air are a factor of 15,000 times lower than those from inhalation and skin absorption of unit concentration of HTO in air (International Commission on Radiological Protection (ICRP), 1995, Age dependent doses to members of the public from intake of radionuclides, Part 4, Inhalation Dose Coefficients. Oxford: Pergamon Press; ICRP Publication 71; Ann. ICRP 25[3\&4]). Thus, doses from inhaled HT can safely be ignored unless the air concentration is extremely high. A release of HT cannot be ignored, however, because HT that reaches the ground is rapidly and efficiently converted to HTO by microorganisms in soil (McFarlane, Rogers, and Bradley, Environmental Science and Technology 12: 590-593,1978; Brown, Ogram, and Spencer, Health Physics 58:171-181, 1990) and to a lesser extent in vegetation (Sweet and Murphy, Environmental Science and Technology, 18:358-361, 1984).

Organically bound tritium (OBT) is formed by plants during photosynthesis and is incorporated by animals when ingested. Animals also metabolize some OBT from ingested or inhaled HTO. The ICRP dose coefficient for OBT is about 2.3 times higher than that of HTO, because the biological half-life of OBT in the body is longer than that of HTO, which is eliminated at the same rate as body water. Although doses predicted by CAP88-PC are generally high enough to account for dose from ingested OBT, nevertheless, a model that explicitly calculates dose from OBT is preferable.

A simple tritium model, NEWTRIT, has been developed that calculates ingestion dose from both HTO and OBT and accounts for conversion of HT to HTO in the environment following releases of HT (Peterson, S-R. and P.A. Davis, Health Physics 82(2): 213-225, 2002). A discussion of the NEWTRIT model was presented in Attachment 2 of the 2000 NESHAPs annual report (Gallegos et al., LLNL NESHAPS 2000 Annual Report, June 2001).

Tritium doses from 2004 Livermore site operations were calculated using NEWTRIT and compared to those obtained by our standard procedure using CAP88-PC (the latter are presented in Section IV). Since NEWTRIT is not a dispersion code, the NEWTRIT model runs used air concentrations of radionuclides as calculated by CAP88-PC. For the principal comparison, the total tritium contribution to the 
Livermore site SW-MEI dose in 2004 as calculated using NEWTRIT was 0.0065 mrem $(0.065 \mu \mathrm{Sv})$, about $14 \%$ lower than the CAP88-PC value of 0.0076 mrem $(0.076$ $\mu \mathrm{Sv})$. Thus, adding in the small contribution to the Livermore site's total dose from radionuclides other than tritium, NEWTRIT would predict a total SW-MEI dose of 0.0068 mrem $(0.068 \mu \mathrm{Sv})$ rather than the value 0.0079 mrem $(0.079 \mu \mathrm{Sv})$ quoted in this report for compliance purposes. Both NEWTRIT and CAP88-PC doses for each significant source of tritium are presented in the data spreadsheet (columns 16 and 19) in the Attachment.

In October 2001, LLNL sent a letter to EPA Region IX requesting consideration of NEWTRIT as an alternative methodology for calculating doses from atmospheric releases of tritiated water vapor (HTO) and tritiated gas (HT), for use in demonstrating compliance with radionuclide NESHAPs (40 CFR 61 Subpart H). In late 2003, the EPA had NEWTRIT coded into GENII-NESHAPs, a version of GENII that the EPA plans to approve as a regulatory model for evaluating radionuclide NESHAPs compliance (B.A. Napier, et al., GENII - The Hanford Environmental Radiation Dosimetry Software System. Richland, WA: Pacific Northwest Laboratory, PNL-6584 Vol. UC-60; 1988). At this writing, GENII-NESHAPs is undergoing peer review and should be approved in late 2005. As well, DOE has surveyed users of CAP88-PC (currently the code most-used for compliance) and determined that there is support to have NEWTRIT incorporated into CAP88-PC.

\section{Comparison of 2004 Modeling Results with Tritium Surveillance Air Monitoring Data}

A comparison was made between CAP88-PC-predicted concentrations of tritium in air and ambient air monitoring data for nine tritiated water vapor samplers on the Livermore site (designated POOL, CAFE, SALV, CRED, VIS, DWTF, COW, B331, and B624). In 2003, an additional four samplers were included in the test of CAP88PC (B514, MESQ, MET, and ZON7, an offsite location). Monitoring was discontinued at Building 514 at the end of December 2003. The other locations were sampled normally, but more than half of their biweekly concentrations were below the lower limits of analytical detection, making any comparison with predicted results meaningless. Figure 5 shoes the locations of the tritium air surveillance monitors. Modeled predictions have been compared with tritium monitoring data since 1997.

Only concentrations from the four most significant sources of tritium releases to air at the Livermore site were included in the model-data comparison. The largest point source for 2004 was the stack at the Decontamination and Waste Treatment Facility (DWTF). Based on ambient air tritium data from the DWTF air tritium sampler and facility knowledge, it was concluded that an estimated $20 \mathrm{Ci}$ HTO were released from the DWTF stack. The release of HTO from the two 30-m-high, continuously-monitored 
stacks at the Tritium Facility (Building 331) was determined from stack monitoring data and emission reconstruction to be $12.1 \mathrm{Ci}\left(4.4 \times 10^{11} \mathrm{~Bq}\right)$ in 2004. (An estimated 4.4 Ci $\left[1.64 \times 10^{11} \mathrm{~Bq}\right]$ of HT emitted from the Tritium Facility stacks is not included in the comparison calculation because the tritium air surveillance monitors register only HTO.) The other two principal sources in our modeling/measurement comparison are open-air diffuse emission areas associated with the Building 612 Yard and the Tritium Facility's outside yard waste accumulation and storage area. Emissions from the Building 612 Yard source were estimated to be $3.2 \mathrm{Ci}\left(1.2 \times 10^{11} \mathrm{~Bq}\right)$, based on calibrating CAP88PC-predictions of tritium concentrations at the tritium monitor B624 closest to it. (Thus the B624 monitor data do not provide a test of the modeling.) Emissions from the Building 331 outside yard source were estimated to be $0.7 \mathrm{Ci}$ $\left(2.6 \times 10^{10} \mathrm{~Bq}\right)$ in 2004 , based on facility knowledge and environmental monitoring data (primarily from the B331 monitor near this yard). While these two diffuse sources contribute significantly to tritium concentrations in all of the monitors, other potential sources of tritiated water vapor release were too minor to influence the overall modeldata comparison.

Annual average concentrations of HTO in air $\left(\mathrm{pCi} / \mathrm{m}^{3}\right)$ at the locations of the eleven monitors were modeled for the four sources individually, and the sum of the four contributions was compared to the measured annual mean concentrations. The results, displayed in Table 12, show that by taking into account the leading sources releasing tritiated water vapor to air, fairly good agreement is obtained between model runs and data for all of the air tritium monitors.

With the exception of small underestimations at COW and DWTF, all air concentrations were overestimated by CAP88-PC, most by more than a factor of two. Thus, in 2004, as in the past, CAP88-PC over-predicts HTO in air from LLNL releases of HTO. This consistent over-prediction since 1997, especially at locations to the south, is probably caused by the relative importance of the diffuse sources for these years (S-R. Peterson, “Testing CAP88-PC's Predicted Air Concentrations Against Historical Air Tritium Monitoring Data, 1986-2001, at Lawrence Livermore National Laboratory," Health Physics 87(6):583-595. 2004). These model predictions are consistent with other tests of CAP88-PC (Peterson op cit; Jack Faucett Associates, Report JACKFAU-341/12-87; 1987). 


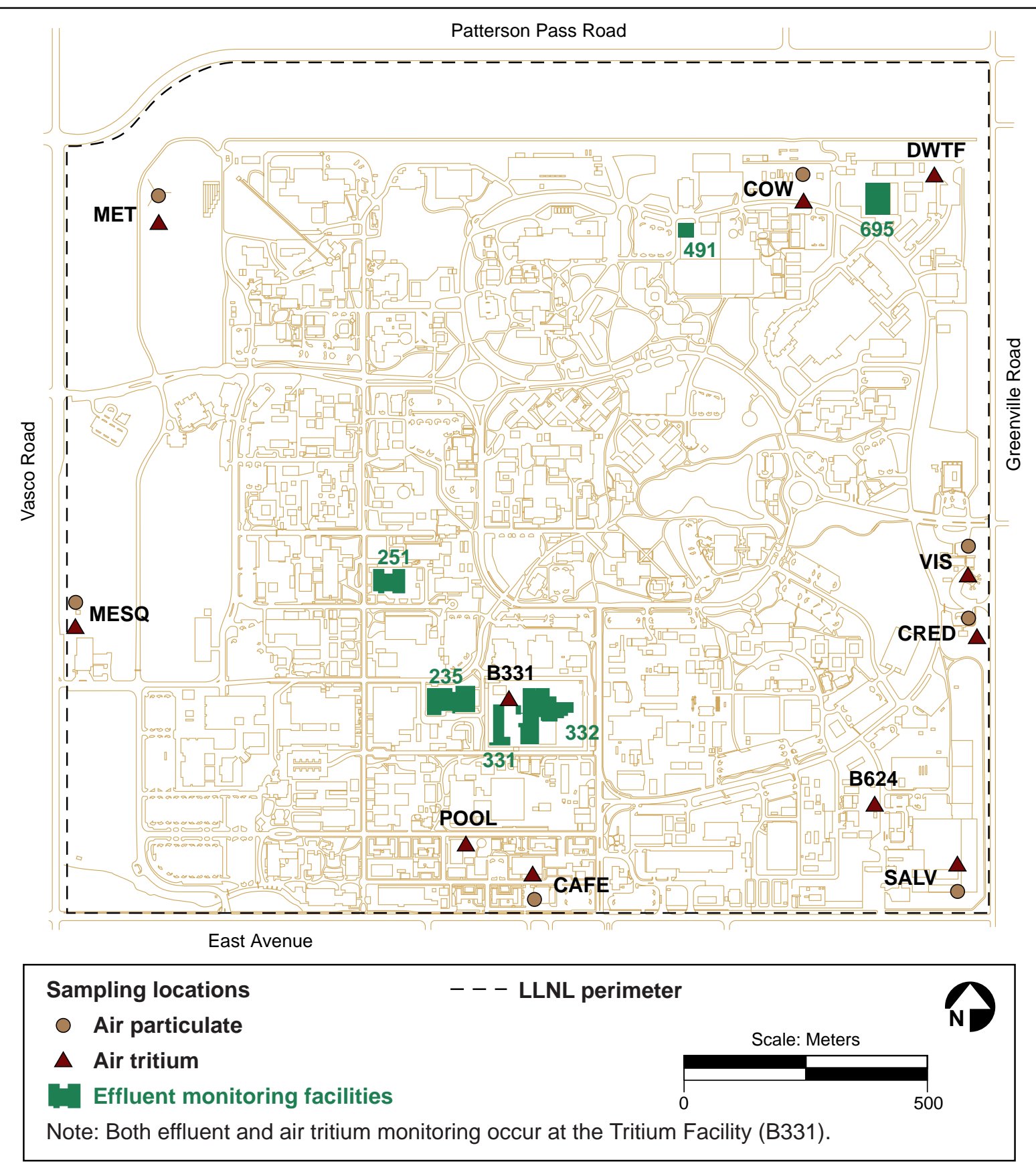

Figure 5. Radiological air monitoring at the Livermore site, showing locations for air surveillance monitoring of tritiated water vapor (triangles) and radioactive particles (circles), and stack air effluent monitoring (indicated by building number and icon). 
Table 12. Comparison of measured and modeled annual mean concentrations of tritiated water vapor (HTO) in air at selected Livermore site locations, 2004.

\begin{tabular}{|c|c|c|c|c|c|c|c|}
\hline \multirow{2}{*}{$\begin{array}{c}\text { Air } \\
\text { monitor } \\
\text { (name) }\end{array}$} & \multirow{2}{*}{$\begin{array}{c}\text { Mean } \\
\text { measured } \\
\text { concentration } \\
\left(\mathrm{pCi} / \mathrm{m}^{3}\right)\end{array}$} & \multirow{2}{*}{$\begin{array}{c}\text { Modeled* } \\
\text { average } \\
\text { concentration } \\
\left(p C i / \mathrm{m}^{3}\right)\end{array}$} & \multirow{2}{*}{$\begin{array}{c}\text { Ratio of } \\
\text { modeled- } \\
\text { to-measured } \\
\text { concentrations }\end{array}$} & \multicolumn{4}{|c|}{$\begin{array}{l}\text { Modeled concentration of tritium in air } \\
\text { contributed by the indicated source }\left(\mathrm{pCi} / \mathrm{m}^{3}\right)\end{array}$} \\
\hline & & & & $\begin{array}{c}\text { B331 } \\
\text { Stacks }\end{array}$ & $\begin{array}{l}\text { B612 } \\
\text { Yard }\end{array}$ & $\begin{array}{l}\text { B331 } \\
\text { WAA }\end{array}$ & $\begin{array}{l}\text { DWTF } \\
\text { Stack }\end{array}$ \\
\hline B624 & 67.9 & 69 & 1.0 & 0.48 & 68.0 & 0.074 & 0.23 \\
\hline B331 & 6.61 & 8.5 & 1.3 & 0.011 & 1.6 & 6.6 & 0.32 \\
\hline DWTF & 2.37 & 2.3 & 0.97 & 0.49 & 0.25 & 0.064 & 1.5 \\
\hline POOL & 2.19 & 2.9 & 1.3 & 0.54 & 1.4 & 0.72 & 0.24 \\
\hline CRED & 1.52 & 3.2 & 2.1 & 0.48 & 2.4 & 0.078 & 0.23 \\
\hline VIS & 1.01 & 2.2 & 2.2 & 0.44 & 1.6 & 0.067 & 0.14 \\
\hline CAFE & 0.992 & 2.0 & 2.0 & 0.25 & 1.3 & 0.19 & 0.24 \\
\hline COW & 0.775 & 0.73 & 0.94 & 0.40 & 0.24 & 0.071 & 0.017 \\
\hline SALV & 0.668 & 1.8 & 2.7 & 0.16 & 1.4 & 0.027 & 0.18 \\
\hline MET & 0.444 & 0.48 & $* *$ & 0.069 & 0.2 & 0.082 & 0.13 \\
\hline ZON7 & 0.408 & 0.73 & $* *$ & 0.16 & 0.17 & 0.015 & 0.38 \\
\hline MESQ & 0.314 & 0.92 & $* *$ & 0.11 & 0.41 & 0.25 & 0.15 \\
\hline
\end{tabular}

* This result takes into account the four most significant tritium sources; it is the annual-mean concentration comprising the sum of the four contributions shown in the far right columns.

** More than half the biweekly samples at these locations were below detection limits. A comparison with predictions is therefore meaningless.

\title{
SECTION VIII. Supplemental Information on Other Compliance
}

\author{
Status of Compliance with Other Regulations \\ Status of compliance with 40 CFR 61 Subpart Q - National Emission \\ Standards for Radon Emissions from Department of Energy Facilities \\ LLNL does not have storage and disposal facilities for radium containing materials \\ that would be a significant source of radon. Emissions of radon from LLNL research \\ experiments did not occur in 2004.
}

\section{Status of compliance with 40 CFR 61 Subpart T - National Emission Standards for Radon Emissions from the Disposal of Uranium Mill Tailings \\ LLNL does not have or store any uranium mill tailings.}




\section{ATTACHMENT. LLNL NESHAPs 2004 Annual Report Spreadsheet}

\section{Guidance for Interpreting the Data Spreadsheet}

A generalized description of each facility and its operations is provided on the spreadsheet. In addition, the following information is shown for each listed emission point or stack:

- $\quad$ Building and room number(s)

- $\quad$ Specific stack identification code(s)

- $\quad$ Generalized description of operations in the room(s) or area(s)

- $\quad$ Radionuclides utilized in the operation

- Annual radionuclide usage inventory with potential for release (by isotope, in curies)

- $\quad$ Physical state factors (by isotope)

- $\quad$ Stack parameters

- $\quad$ Emission control devices and emission control device abatement factors

- $\quad$ Estimated or measured annual emissions (by isotope)

- $\quad$ Distance and direction to the site-wide maximally exposed individual (SWMEI)

- $\quad$ Calculated EDE to the SW-MEI

- $\quad$ Distance and direction to the maximally exposed individual for that specific source (MEI)

- $\quad$ Calculated EDE to the MEI (source term not adjusted for emission controls)

- $\quad$ Source category

\section{Radionuclides}

The radionuclides shown in the spreadsheet are those from specific emission points where air emissions were possible. If radionuclides were present, but encapsulated or sealed for the entire year, radionuclides, annual usage inventories, and emissions are not listed.

\section{Radionuclide Usage Inventories}

The annual radionuclide usage inventories for point source locations are based on data from facility experimenters and managers. For Buildings 251 (hardened area) and 332, classification issues regarding transuranic radionuclide usage inventories make use of the usage inventory/modeling approach impractical. However, all such affected emission points in these buildings are continuously monitored, and emissions are therefore directly determined.

\section{Physical State Factors}

The physical state factors listed are EPA potential release fractions from 40 CFR 61, Appendix D, whereby emissions are estimated from radionuclide usage inventories 
depending on their physical states for use in dispersion/dose assessment modeling. A physical state factor of $1.0 \times 10^{-6}$ is used for solids, $1.0 \times 10^{-3}$ is used for liquids and powders, and 1.0 is used for unconfined gases and substances heated above $100^{\circ} \mathrm{C}$. Regarding the latter, U.S. EPA has granted LLNL approved alternative emissions factors for selected radionuclides (see Table 7 in Section III.) These factors are allowed provided that the material is not intentionally dispersed to the environment and that the processes do not alter the chemical form of the material.

\section{Stack Parameters}

Stack physical parameters for sources evaluated in 2004 were updated, as necessary, by experimenters and managers for those facilities. TAMM Group annually measures the stack velocity of each monitored stack.

\section{Emission Control Devices}

High Efficiency Particulate Air (HEPA) filters are used in many LLNL facilities to control particulate emissions. For some discharge points, scrubbers and electrostatic precipitators aid the control of emissions. The operational performance of all HEPA filtration systems is routinely tested. The required efficiency of a single stage HEPA filter is $99.97 \%$. Double staged filter systems are in place on some discharge points. Triple stage HEPA filters are used on glove box ventilation systems in the Building 332 Plutonium Facility and in the hardened portion of Building 251.

\section{Control Device Abatement Factors}

Similar to physical state factors, control device abatement factors, from Table 1 in 40 CFR 61, Appendix D, are those associated with the listed emission control devices, and are used to better estimate actual emissions for use in dispersion and dose models. By regulation, each HEPA filter stage is given a 0.01 factor (even though the required test efficiency that all LLNL HEPA filters must maintain would yield a factor of 0.0003).

\section{Estimated Annual Emissions}

For unmonitored and non-continuously monitored sources, estimated annual emissions for each radionuclide are based on the product of (1) usage inventory data, (2) time factors (discussed in "Emission Source Terms" in Section III), (3) EPA potential release fractions (physical state factors), and (4) applicable emission control device abatement factors.

Actual emission measurements are the basis for reported emissions from continuously monitored facilities. LLNL facilities that had continuous monitoring systems in 2004 were Buildings 235, 251, 331, 332, 491, and 695/696 at the Livermore site, and Building 801A (the Contained Firing Facility) at Site 300, as noted earlier in the subsection on "Compliance with 40 CFR Subpart H (61.93)" in Section IV. See also the discussion below under "0.1 mrem/y Monitoring Requirement" regarding the use of emissions measurements for monitored sources. 


\section{$10 \mathrm{mrem} / \mathrm{y}$ Site-Wide Dose Requirement}

For LLNL to comply with the NESHAPs regulations, the LLNL site-wide maximally exposed individual (SW-MEI; defined as the hypothetical member of the public at a single residence, school, business, or office who receives the greatest LLNL-induced EDE from the combination of all radionuclide source emissions) cannot receive an EDE greater than $10 \mathrm{mrem} / \mathrm{y}(100 \mu \mathrm{Sv} / \mathrm{y})$. (See Section III for a discussion of the SW-MEI.)

In the spreadsheet, the distance and direction to the respective SW-MEI are shown for each facility at each site. Doses to the site specific SW-MEIs were evaluated for each source and then totaled for site-specific evaluations against the $10 \mathrm{mrem} / \mathrm{y}$ dose standard (see Section IV).

\section{$0.1 \mathrm{mrem} / \mathrm{y}$ Monitoring Requirement}

To assess compliance with the requirement for continuous monitoring (potential dose greater than $0.1 \mathrm{mrem} / \mathrm{y}[1.0 \mu \mathrm{Sv} / \mathrm{y}$ ] to the maximally-exposed public individual or MEI, discussed earlier in Section III), emissions must be individually evaluated from each point source. The location of the MEI is generally different for each emission point. The maximum dose at a location of unrestricted public access typically occurs at a point on the site perimeter. Therefore, it is often referred to as the maximum "fence line" dose, although the off-site maximum dose could occur some distance beyond the perimeter. (This could happen, e.g., when the perimeter is close to a stack; however, for nearly all emission points at the Livermore site and Site 300, calculations show that ground level concentrations of radionuclides generally decline continuously beyond LLNL boundaries.) As stipulated by the regulations, modeling for assessment of continuous monitoring requirements assumed unabated emissions (i.e., no credit was taken for emission abatement devices, such as filters), but physical state factors and time factors were applied.

The unabated EDE cannot be calculated for HEPA-filtered facilities monitored for radioactive particles. Because the monitoring equipment is placed after HEPA filtration, there is no way to obtain an estimate for what the emissions might have been had there been no filtration. It is not reasonable to apply factors for the effects of the HEPA filters on the emission rate because most of what is measured on the HEPA filters is the result of the radioactive decay of radon, which is capable of penetrating the filter. The spreadsheet gives, for each inventoried point source, the dose to the MEI and the distance and direction to the LLNL fence line where the MEI is located. However, for HEPA-filtered monitored sources, no value is shown.

\section{Source Categories}

LLNL radionuclide air emission sources have been classified into seven source categories, indicated by the number in the last column of the following spreadsheet: (1) Unmonitored or non-continuously monitored Livermore-site facilities that have had a radionuclide usage inventory update for 2004; (2) Unmonitored or non-continuously monitored Livermore site facilities with a previous radionuclide usage inventory update (this category is not used in 
years with complete usage inventory updates, such as 2000); (3) Continuously monitored Livermore site and Site 300 facilities; (4) Site 300 explosives experiments; (5) Diffuse sources where emissions and subsequent doses were estimated using inventory processes; (6) Diffuse sources where emission and dose estimates were supported by environmental surveillance measurements; and (7) Sources whose emissions estimates and subsequent doses were estimated by confirmatory air sampling rather than continuous sampling. 


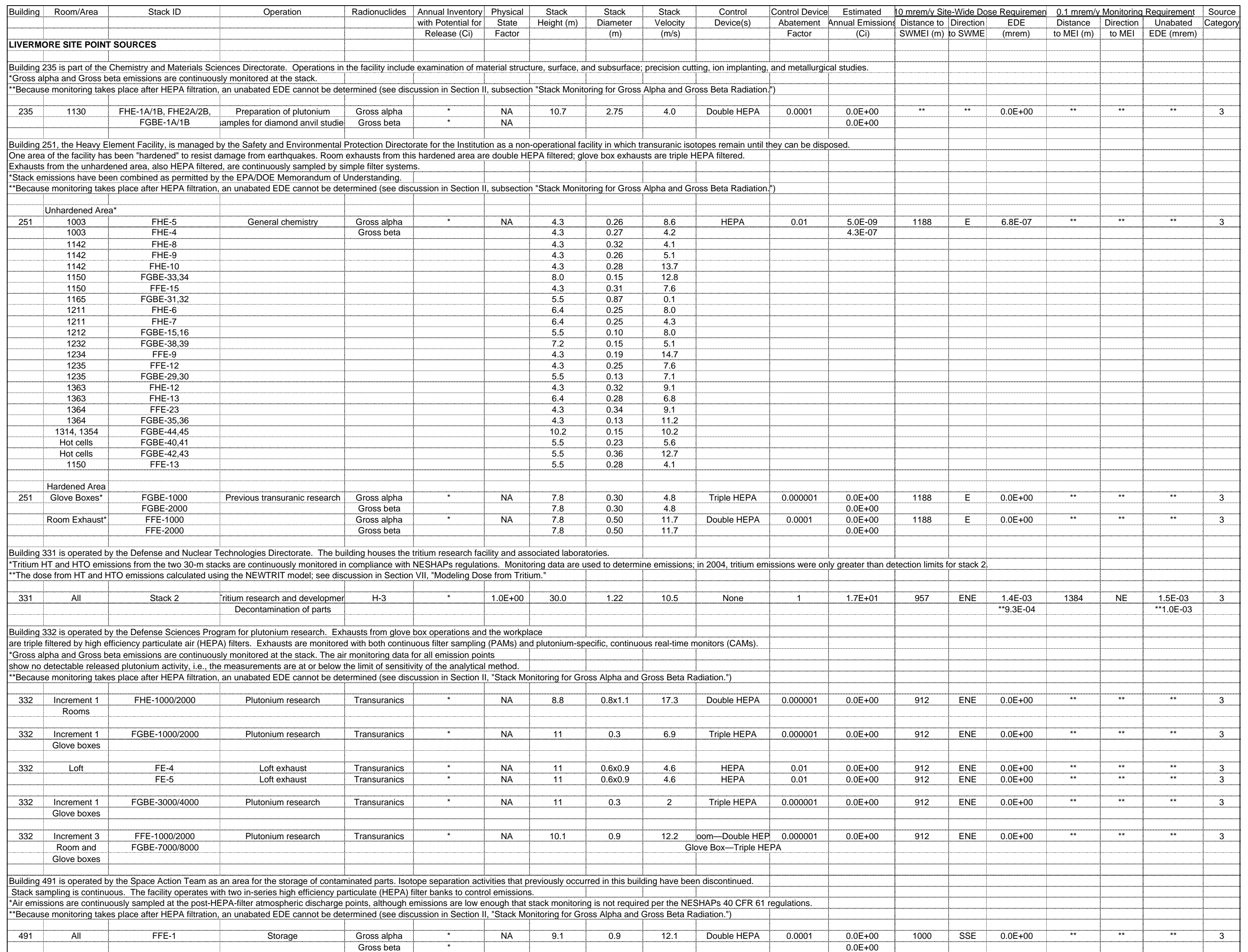




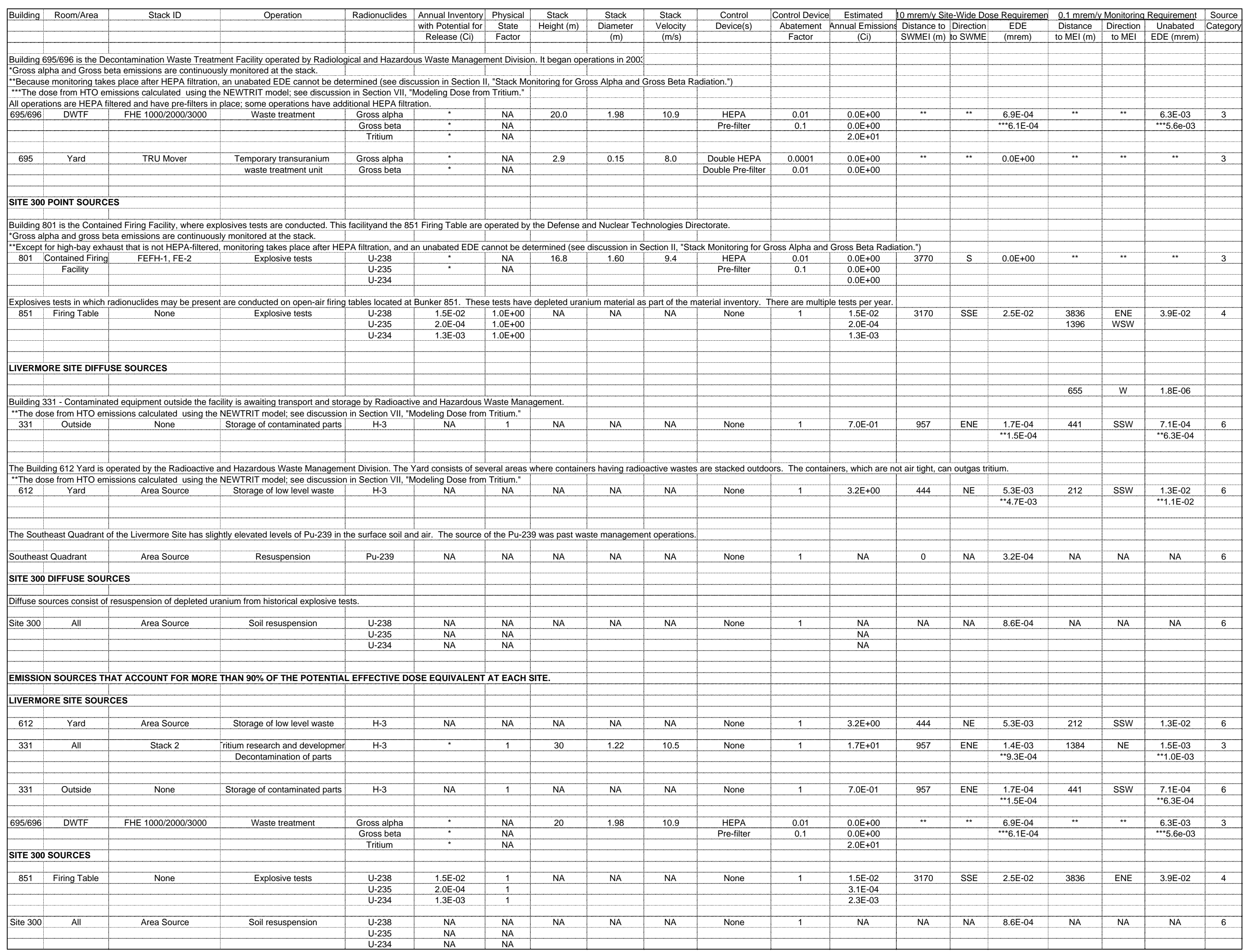

